


\section{PROCUREMENT RISK FRAMEWORK GUIDANCE NOTE ON PROCUREMENT}

DECEMBER 2021 
(C) 2021 Asian Development Bank

6 ADB Avenue, Mandaluyong City, 1550 Metro Manila, Philippines

Tel +6328632 4444; Fax +63286362444

www.adb.org

Some rights reserved. Published in 2021.

ISBN 978-92-9269-265-0 (print), 978-92-9269-266-7 (electronic)

Publication Stock No. TIM210527-2

DOI: http://dx.doi.org/10.22617/TIM210527-2

The views expressed in this publication are those of the authors and do not necessarily reflect the views and policies of the Asian Development Bank (ADB) or its Board of Governors or the governments they represent.

ADB does not guarantee the accuracy of the data included in this publication and accepts no responsibility for any consequence of their use. The mention of specific companies or products of manufacturers does not imply that they are endorsed or recommended by ADB in preference to others of a similar nature that are not mentioned.

By making any designation of or reference to a particular territory or geographic area, or by using the term "country" in this document, ADB does not intend to make any judgments as to the legal or other status of any territory or area.

This work is available under the Creative Commons Attribution-NonCommercial-NoDerivs 3.0 IGO license (CC BY-NC-ND 3.0 IGO) http://creativecommons.org/licenses/by-nc-nd/3.0/igo/. By using the content of this publication, you agree to be bound by the terms of this license. For attribution and permissions, please read the provisions and terms of use at https://www.adb.org/terms-use\#openaccess.

This CC license does not apply to non-ADB copyright materials in this publication. If the material is attributed to another source, please contact the copyright owner or publisher of that source for permission to reproduce it. ADB cannot be held liable for any claims that arise as a result of your use of the material.

Please contact pubsmarketing@adb.org if you have questions or comments with respect to content, or if you wish to obtain copyright permission for your intended use that does not fall within these terms, or for permission to use the ADB logo.

Corrigenda to ADB publications may be found at http://www.adb.org/publications/corrigenda.

Notes:

In this publication, "\$" refers to United States dollars. 
Tables and Figures

About This Publication vi vi vis

Abbreviations $\quad$ ix

Executive Summary $\quad x$

$\begin{array}{ll}\text { I. Introduction } & 1\end{array}$

$\begin{array}{ll}\text { II. Purpose } & 4\end{array}$

III. The Procurement Risk Framework 5

IV. Risk Assessment and Treatment $\quad 12$

V. Risk Management in the Procurement Cycle $\quad 14$

$\begin{array}{ll}\text { VI. Resources for Further Review } & 17\end{array}$

Appendixes

1 Risk Assessment Tables $\quad 18$

2 Country and Sector/Agency Procurement 20 Risk Assessment Process

3 Country Procurement Data Sheet 28

4 Country Procurement Assessment Tool 33

5 Indicative Terms of Reference for a Country 41 and Sector/Agency Procurement Risk Assessment
Sector/Agency Procurement Assessment Tool

$\begin{array}{lll}6 & \text { Sector/Agency Procurement Assessment Tool } & 43 \\ 7 & \text { Report Outline for a Country and Sector/Agency } & 59\end{array}$ Procurement Risk Assessment

8 Potential Risks from a Country and Sector/Agency 63 Procurement Risk Assessment

9 Procurement Risk Assessment and Management 67 Plan Template

10 Concept Stage Procurement Risk Rating Tool 68

11 Sector Market Analysis Examples $\quad 70$ 


\section{TABLES AND FIGURES}

\section{TABLES}

1. Applicability of Risk Management Tools $\quad 7$ to Organizational/Entity Level

2. Responsibilities for Risk Management in the Procurement Cycle 9

3. A Comparison Between CSPRA and MAPS Assessments 17

$\begin{array}{lll}\text { A1.1. } & \text { Risk Likelihood } & 18\end{array}$

$\begin{array}{ll}\text { A1.2. Risk Consequence } & 18\end{array}$

$\begin{array}{ll}\text { A1.3. Risk Rating Matrix } & 19\end{array}$

A1.4. Risk Rating Key 19

A2. Example of How a Procurement Weakness May Convert to a Risk 26

A3. Procurement Data Table 28

A4.1. Country Procurement Assessment Tool 33

A4.2. Country Procurement Assessment Tool Scoring Guide 35

A6.1. Sector/Agency Procurement Assessment Tool 43

A6.2. Sector/Agency Procurement Assessment Tool Scoring Guide $\quad 49$

A10. Concept Stage Project Procurement Risk Rating Tool 64

A11. Sector Bid Evaluation Report Analysis Example 72 


\section{FIGURES}

1. Risk Management's Contribution to Value for Money 2

2. The ADB Procurement Cycle 3

3. The Procurement Risk Framework 5

4. The Risk Management Process 6

5. Risk Management through Planning, Bidding, and Implementation 11

$\begin{array}{ll}\text { 6. } & \text { Risk Treatment Options } \\ \end{array}$

7. The Country and Sector/Agency Procurement 15 Risk Assessment Process

A11. Sector Contract Awards Data Analysis Example 70 


\section{ABOUT THIS PUBLICATION}

In April 2017, the Asian Development Bank (ADB) approved its new procurement framework, the ADB Procurement Policy: Goods, Works, Nonconsulting and Consulting Services (2017, as amended from time to time); and the Procurement Regulations for ADB Borrowers: Goods, Works, Nonconsulting and Consulting Services (2017, as amended from time to time). These replace the former Guidelines on the Use of Consultants (2013, as amended from time to time) and Procurement Guidelines (2015, as amended from time to time). The procurement policy and the procurement regulations address the procurement activities of project executing agencies and implementing agencies on projects financed in whole or in part by a loan or grant from ADB, or by ADB-administered funds. ADB designed the 2017 procurement policy to deliver significant benefits and flexibility throughout the project procurement cycle, as well as to improve project delivery through a renewed focus on the concepts of quality, value for money (VFM), and fitness for purpose.

This note is part of a series of guidance notes published by ADB in 2018 to accompany the 2017 procurement policy and the procurement regulations. Each note discusses a topical issue for borrowers (including grant recipients), bidders, and civil society under the new framework (see list below). The guidance notes cross-reference each other frequently and should be read in conjunction. All references to "guidance notes" pertain to these notes. The notes may be updated, replaced, or withdrawn from time to time.

\section{List of Guidance Notes for the 2017 ADB Procurement Policy and the Procurement Regulations}

1. Value for Money

2. Procurement Risk Framework

3. Strategic Procurement Planning

4. Procurement Review

5. Alternative Procurement Arrangements

6. Open Competitive Bidding

7. Price Adjustment

8. Abnormally Low Bids

9. Domestic Preference

10. Prequalification

11. Subcontracting

12. Consulting Services Administered by ADB Borrowers

13. Nonconsulting Services Administered by ADB Borrowers
14. High-Level Technology

15. Quality

16. Bidding-Related Complaints

17. Noncompliance in Procurement

18. Standstill Period

19. State-Owned Enterprises

20. E-Procurement

21. Framework Agreements for Consulting Services

22. Public-Private Partnerships

23. Contract Management

24. Fragile, Conflict-Affected, and Emergency Situations

25. Sustainable Public Procurement

26. Use of Merit Point Criteria for Bid Evaluation 
ADB procurement reforms intend to ensure VFM by improving flexibility, quality, and efficiency throughout the procurement cycle (see illustration below and the Guidance Note on Value for Money). VFM is part of a holistic procurement structure with three support pillars: efficiency, quality, and flexibility. The two key principles of transparency and fairness weave across all elements of the structure.

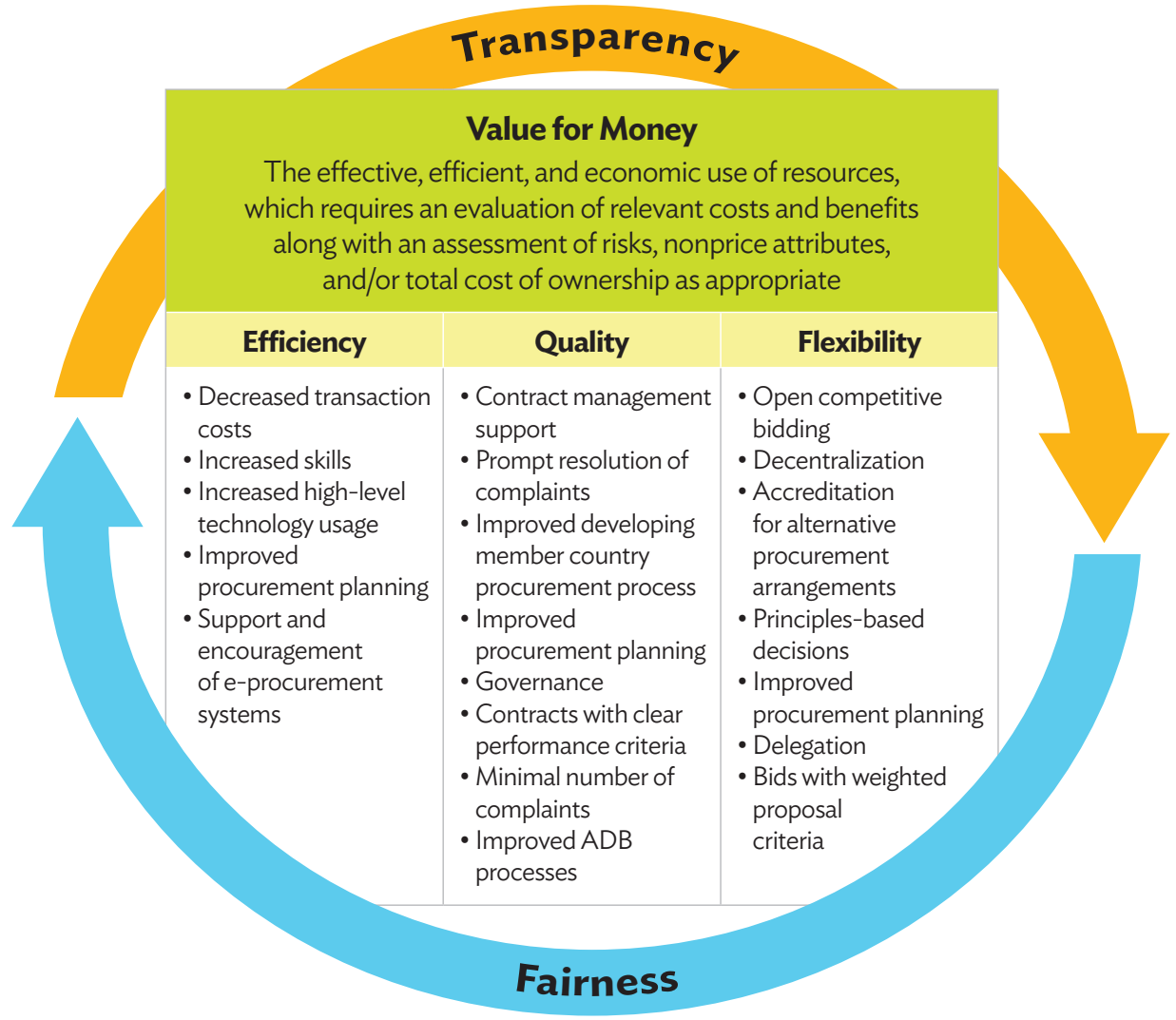

\section{(1) Time}

Time is an important element of VFM. When a project is delivered promptly or when a process is completed rapidly, greater value is created for all stakeholders. For example, a road project completed early provides economic benefit, security, or other value to the community it serves. It increases the return on investment to the executing agency and accelerates the project and payment cycle to the successful bidder. Likewise, a project delivered late loses significant value.

When considering VFM in the context of procurement, pay attention to anything that (i) shortens the procurement cycle time frame or (ii) accelerates delivery of the development project. 


\section{$\Omega$ Objective}

This guidance note is intended to assist readers by elaborating on and explaining ADB's 2017 procurement policy and procurement regulations for borrowers (including grant recipients).

This note identifies additional information for the reader to consider when applying ADB's procurement policy and procurement regulations to their circumstances.

\section{Eiving Document}

This guidance note is intended to be a living document and will be revised as required.

Be sure to check the ADB Business Center website for the latest version and updates, https://www.adb.org/business/main.

\section{? The Reader}

In many circumstances, readers are expected to use this guidance note in a manner unique to their needs. For consistency throughout the suite of guidance notes, the following assumption is made about the reader:

The reader is a professional involved in activities financed in whole or in part by an ADB loan or grant, or by ADB-administered funds.

\section{FAQs}

Frequently asked questions, clarifications, examples, additional information, links to training, and other useful resources will be made available on the ADB website.

Be sure to check the ADB Business Center website for more information, https://www.adb.org/business/main.

\section{Legal and Order of Priority}

This guidance note explains and elaborates on the provisions of the Procurement Regulations for ADB Borrowers: Goods, Works, Nonconsulting and Consulting Services (2017, as amended from time to time) applicable to executing (and implementing) agencies under sovereign (including subsovereign) projects financed in whole or in part by an investment loan from ADB (i.e., excluding ADB results- or policy-based loans), ADB-financed grant (excluding ADB-administered technical assistance and staff consultancies), or by ADB-administered funds.

In the event of any discrepancy between this guidance note and the procurement regulations, the latter will prevail. The financing agreement governs the legal relationships between the borrower and ADB. The rights and obligations between the borrower and the provider of goods, works, or services are governed by the specific procurement document issued by the borrower and by the contract signed between the borrower and the provider, and not by this guidance note. 


\section{ABBREVIATIONS}

\begin{tabular}{|c|c|c|}
\hline $\mathrm{ADB}$ & - & Asian Development Bank \\
\hline CMP & - & contract management plan \\
\hline CPAR & - & country procurement assessment report \\
\hline CPRM & - & country portfolio review mission \\
\hline CPS & - & country partnership strategy \\
\hline CSPRA & - & $\begin{array}{l}\text { country and sector/agency procurement } \\
\text { risk assessment }\end{array}$ \\
\hline e-GP & - & electronic government procurement \\
\hline MAPS & - & Methodology for Assessing Procurement Systems \\
\hline OAI & - & Office of Anticorruption and Integrity \\
\hline P-RAMP & - & $\begin{array}{l}\text { procurement risk assessment } \\
\text { and management plan }\end{array}$ \\
\hline PEFA & - & Public Expenditure and Financial Accountability \\
\hline PPRA & - & project procurement risk assessment \\
\hline PPRR & - & project procurement-related review \\
\hline SPP & - & strategic procurement plan \\
\hline VFM & - & value for money \\
\hline
\end{tabular}




\section{EXECUTIVE SUMMARY}

This guidance note describes ADB's procurement risk framework for managing procurement risk throughout the procurement cycle. The purpose of risk management is to minimize impacts on project objectives from adverse events. The guidance note describes how risks are identified, assessed, and managed at the country and sector/agency levels, and how those risks are used as inputs into the identification, assessment, and management of risk at the project level during procurement planning and through contract implementation.

The procurement risk framework emphasizes the need to treat and manage risks after identification and highlights risk management as an ongoing activity. Assessments and risk treatments need to be updated on a continuous basis, as risks change and new risks are identified.

Effectively identifying and mitigating procurement-related risks may

\section{Increase Efficiency and Reduce Procurement Time}

- The procurement risk framework describes how the outputs of risk assessments are used as inputs into risk assessment at subsequent stages, thereby ensuring continuity in the risk management process and precluding the need to develop each successive assessment from the beginning.

- Effective risk management reduces the probability of project delays.

\section{Reduce Risk}

- The procurement risk framework describes the process for assessing risks and treatment options, enabling risks to be mitigated.

\section{Deliver Value for Money}

- Value for money and risk are intrinsically linked. Effective management of risk leads directly to enhanced value for money and ultimately to an increased likelihood of achieving project objectives. 


\section{Introduction}

1.1 This guidance note describes the procurement risk framework of the Asian Development Bank (ADB) for managing procurement risk throughout the procurement cycle from country partnership strategy to contract closeout. The purpose of risk management is to minimize the impacts of possible adverse events on achievement of the objectives of a project financed in whole or in part by an ADB loan or grant, or by ADB-administered funds.

1.2 The procurement risk framework describes how risks are identified, assessed, and managed at the country and sector/agency levels and how those risks are used as inputs into the identification, assessment, and management of risk at the project level.

1.3 The framework emphasizes the need to treat and manage risks after identification and highlights that risk management is an ongoing activity. Assessments and risk treatments need to be updated on a continuous basis as risks change and new risks are identified.

1.4 The framework is principles-based and not compliance-based, in line with the ADB Procurement Policy: Goods, Works, Nonconsulting and Consulting Services (2017, as amended from time to time) and Procurement Regulations for ADB Borrowers: Goods, Works, Nonconsulting and Consulting Services (2017, as amended from time to time). This approach supports ADB's core procurement principles of economy, efficiency, fairness, transparency, quality, and value for money (VFM).

1.5 Risk management and VFM are closely linked. Figure 1 describes how VFM depends on quality, cost, and sustainability, with each of these aspects incorporating the components listed. Adverse impacts to any of these three aspects can adversely impact VFM:

(i) An increase in the cost of a procurement or project directly impacts VFM, if it is not associated with improvements in quality or sustainability.

(ii) Lower quality adversely impacts VFM, if it is not associated with compensating reductions in cost.

(iii) Adverse sustainability outcomes, such as environmental pollution or poor project or operational safety, have either direct or downstream impacts on VFM. Even if quality and cost objectives are met, achieving these at the cost of damage to the environment compromises VFM. 
Figure 1: Risk Management's Contribution to Value for Money

- Buildability

- Functionality

- Maintainability

- Operability

Quality

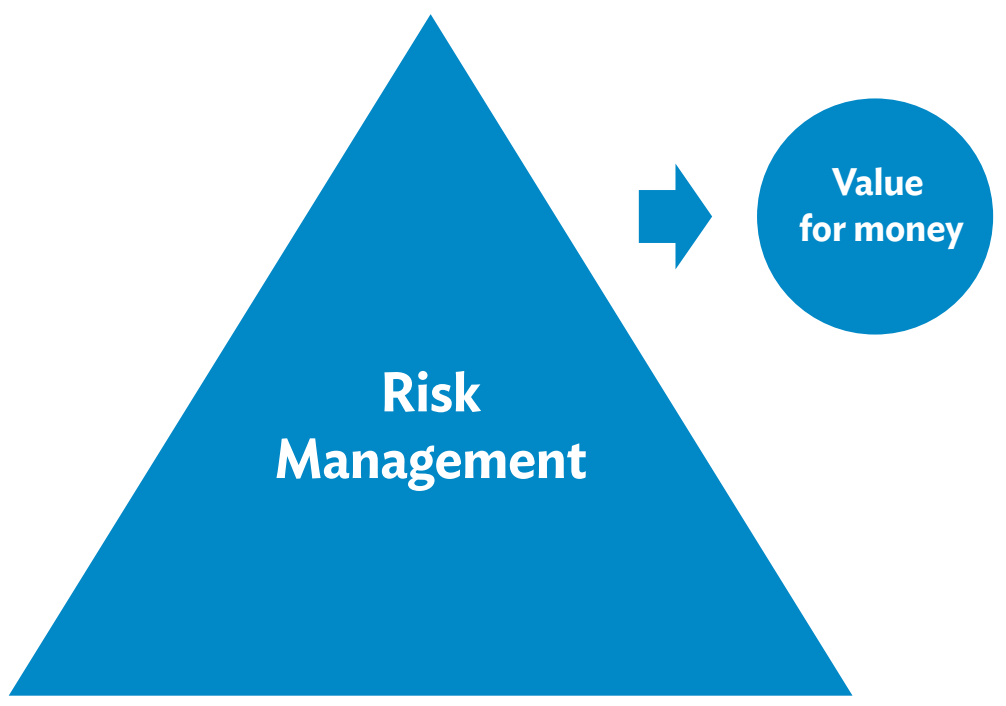

Cost

Sustainability

- Purchase cost

- Life cyle costs

- Schedule

- Environment

- Safety

- Probity

- Economic development

- Local procurement

Source: Asian Development Bank. 
1.6 Risk management is an essential part of the ADB procurement cycle because it ensures that risks to quality, cost, and sustainability are identified and mitigated so that VFM and project objectives are more likely to be achieved. Figure 2 shows the ADB procurement cycle.

Figure 2: The ADB Procurement Cycle

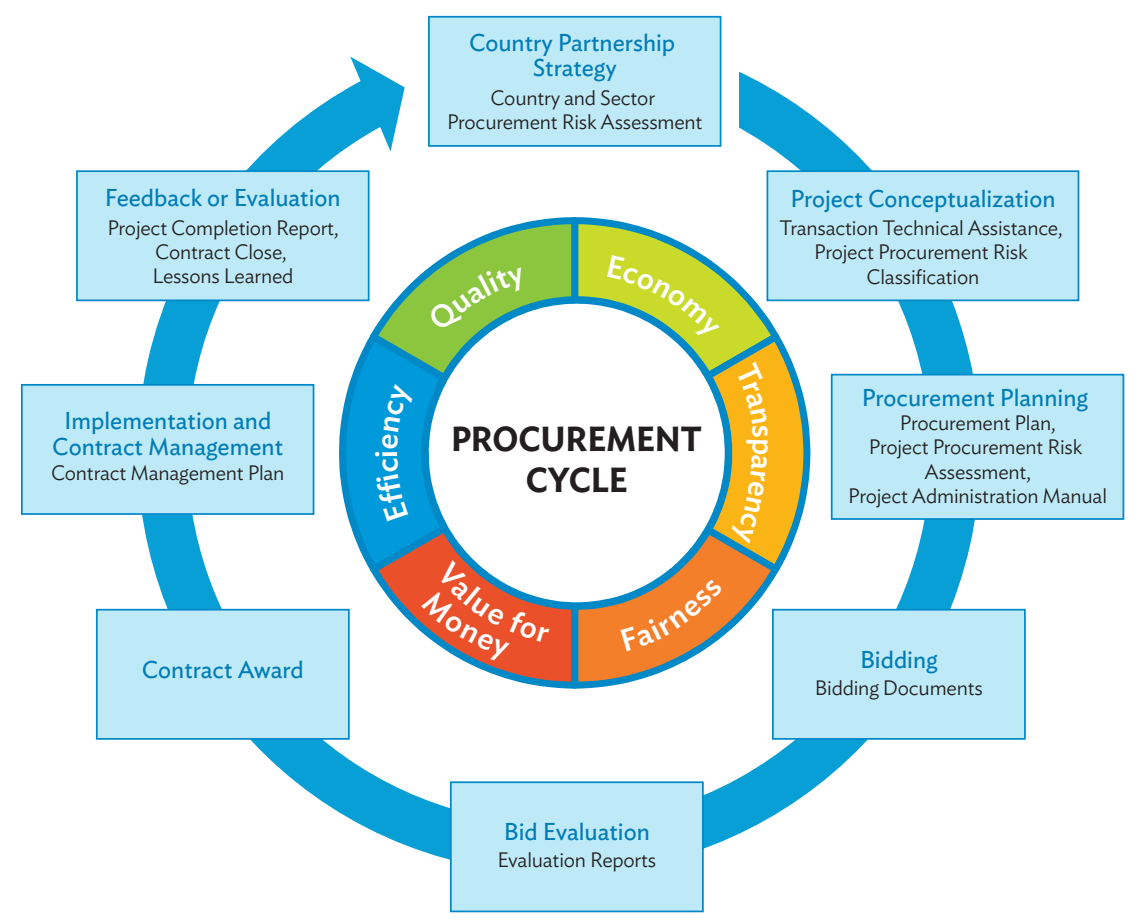

Source: Asian Development Bank. 


\section{Purpose}

2.1 The purpose of this guidance note is to present ADB's procurement risk framework and explain how it is applied at each stage of the procurement cycle.

2.2 The procurement risk framework applies to different entity/organizational levels (country, sector/agency, and project) and to each stage of the project life cycle-a continuous process that cascades through the project and procurement cycles.

2.3 The borrower (or grant recipient) and ADB are responsible for managing risk at different stages of the procurement cycle, and they need to work together to ensure that risks are identified and managed effectively. While the borrower is directly responsible for such actions, ADB has a fiduciary responsibility to ensure risks are identified and managed within country and sector strategies, and at agency and project levels. 


\section{The Procurement Risk Framework}

3.1 Figure 3 describes the ADB procurement risk framework.

Figure 3: The Procurement Risk Framework

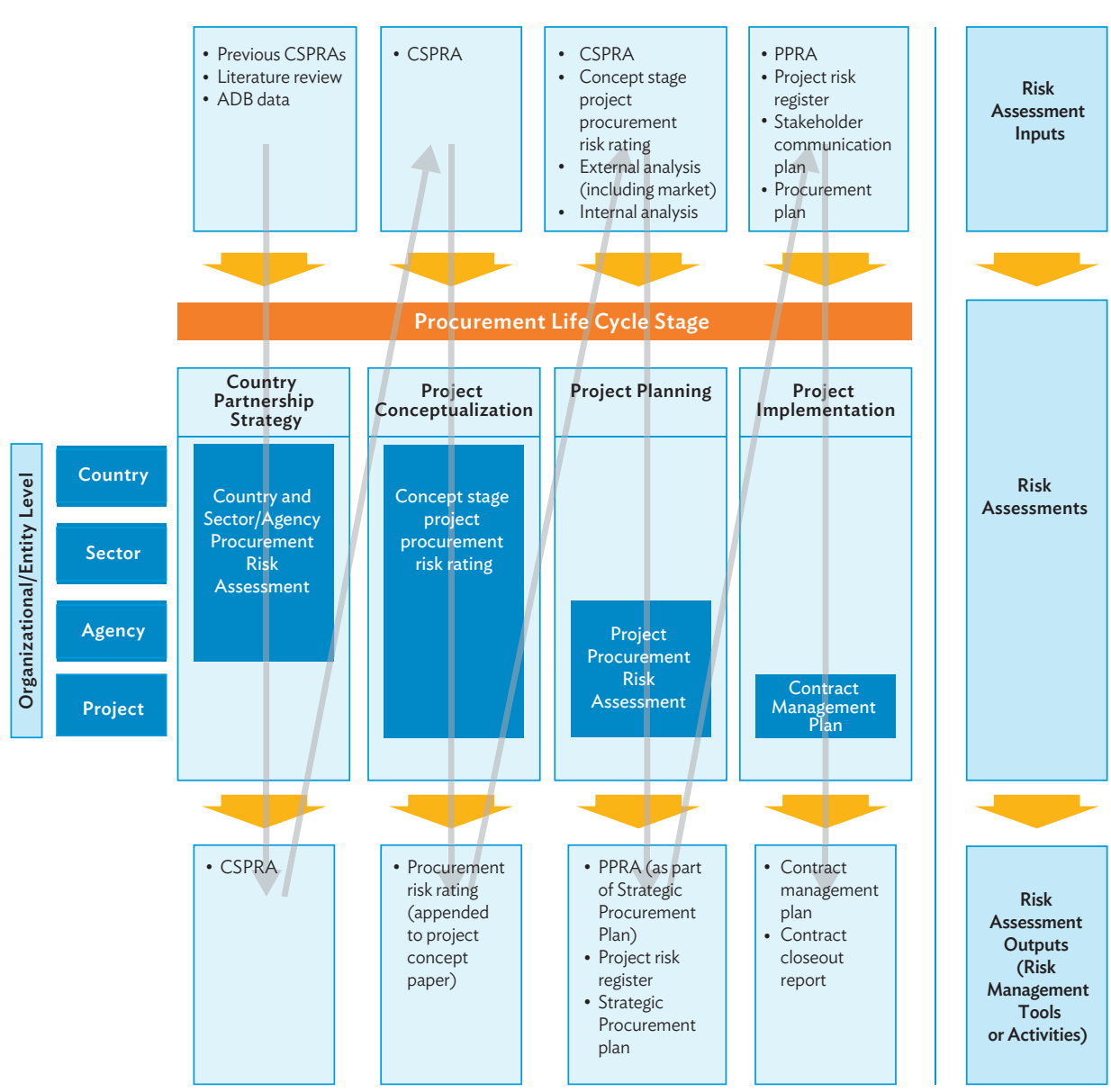

$\mathrm{ADB}=$ Asian Development Bank, CSPRA = country and sector/agency procurement risk assessment, PPRA = project procurement risk assessment.

Source: Asian Development Bank. 
3.2 The procurement risk framework is based on the following principles:

(i) It is structured around the risk management process.

(ii) It applies at different organizational/entity levels.

(iii) It applies throughout the procurement cycle.

(iv) It is continuous and cascades through the procurement cycle.

(v) Risks must be managed after identification.

\section{A. Procurement Risk Framework Structured around the Risk Management Process}

3.3 The procurement risk framework is structured around the risk management process in Figure 4, beginning with the identification of risks.

Figure 4: The Risk Management Process

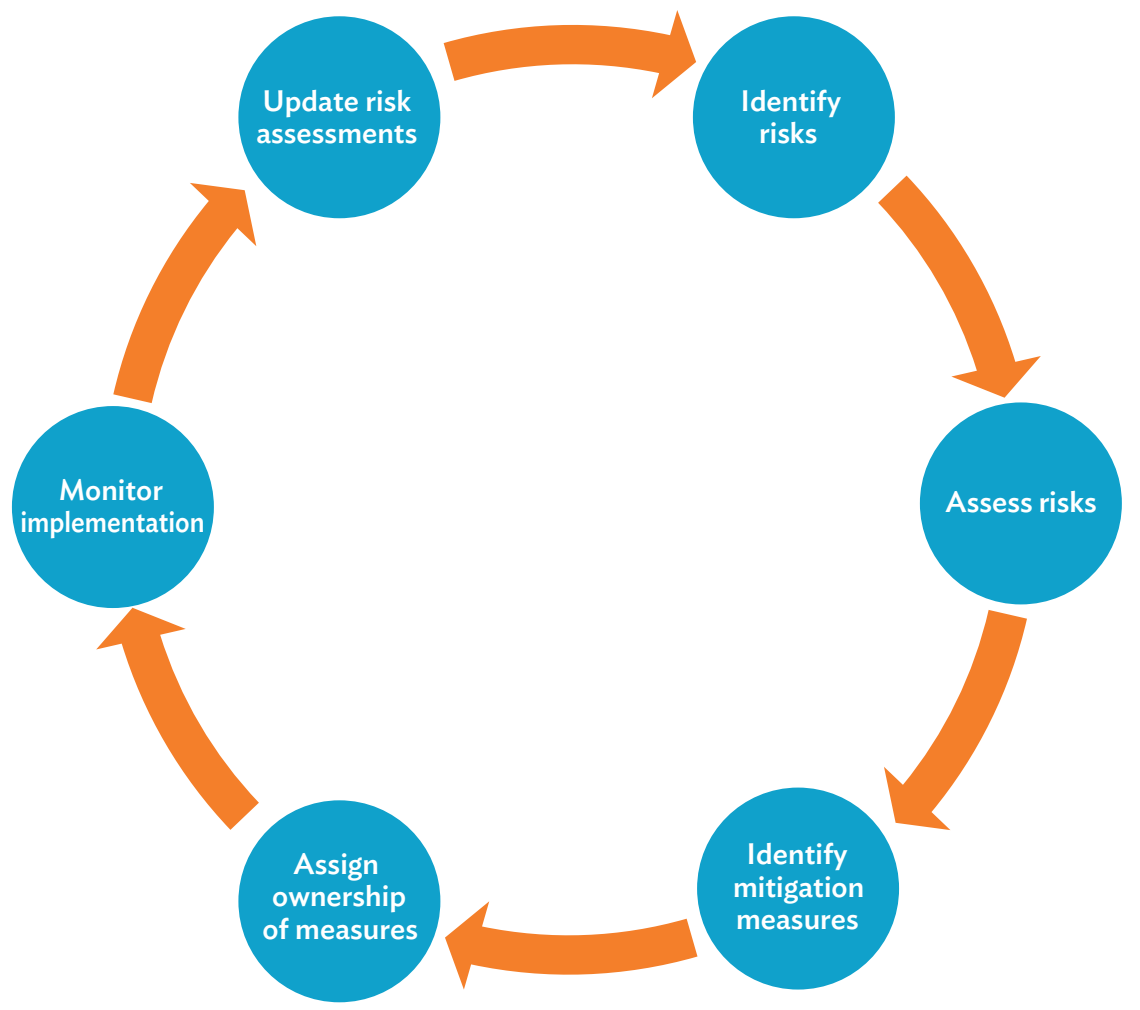

Source: Asian Development Bank. 
3.4 The procurement risk framework in Figure 3 shows the inputs used for the identification of risks at each stage of the procurement cycle. These inputs are used to assist in the identification of risks at each stage. Risks are then assessed in terms of likelihood and consequence. The output of the risk assessment process is the identification and implementation of measures to mitigate the risks. Implementation of the mitigation measures happens via the measures being assigned to the appropriate party to action as required. Progress on the mitigation measures should be monitored on a continuous basis to ensure that they are implemented and effective. Finally, risk assessments should be updated to reflect any changes to risks or any new risks.

\section{B. The Procurement Risk Framework Applies at Different Organizational/Entity Levels}

3.5 The procurement risk framework applies at the country, sector/agency, and project levels. Figure 3 shows the different types of risk assessment performed at each stage of the procurement cycle and these are listed in Table 1.

Table 1: Applicability of Risk Management Tools to Organizational/Entity Level

\begin{tabular}{|c|c|c|c|c|c|}
\hline \multirow[b]{2}{*}{ Risk Management Tool } & \multicolumn{4}{|c|}{ Application } & \multirow[b]{2}{*}{ Comment } \\
\hline & Country & Sector & Agency & Project & \\
\hline $\begin{array}{l}\text { Country and Sector/ } \\
\text { Agency Procurement } \\
\text { Risk Assessment } \\
\text { (CSPRA) }\end{array}$ & $\checkmark$ & $\checkmark$ & $\checkmark$ & & $\begin{array}{l}\text { CSPRA considers } \\
\text { procurement risks } \\
\text { associated with the } \\
\text { country and sector/ } \\
\text { agency procurement } \\
\text { capability }\end{array}$ \\
\hline $\begin{array}{l}\text { Concept Stage Project } \\
\text { Procurement Risk Rating }\end{array}$ & $\checkmark$ & $\checkmark$ & $\sqrt{ }$ & $\checkmark$ & $\begin{array}{l}\text { In rating the project } \\
\text { procurement risk, the } \\
\text { CSPRA is considered } \\
\text { along with project risks }\end{array}$ \\
\hline $\begin{array}{l}\text { Project Procurement } \\
\text { Risk Assessment (PPRA) }\end{array}$ & & & $\checkmark$ & $\checkmark$ & $\begin{array}{l}\text { Agency capability } \\
\text { is considered in the } \\
\text { PPRA as well as project } \\
\text { procurement risks }\end{array}$ \\
\hline $\begin{array}{l}\text { Contract Management } \\
\text { Plan (CMP) }\end{array}$ & & & & $\checkmark$ & $\begin{array}{l}\text { Relevant risks in the } \\
\text { risk register carry } \\
\text { through to the CMP }\end{array}$ \\
\hline
\end{tabular}

CSPRA = country and sector/agency procurement risk assessment, PPRA = project procurement risk assessment, $\mathrm{CMP}=$ contract management plan.

Source: Asian Development Bank. 


\section{The Procurement Risk Framework Applies throughout the Procurement Cycle}

3.6 The procurement risk framework preferably begins in advance of preparation of the country partnership strategy (CPS). At this time, a CSPRA is developed, identifying risks at the country and sector/agency levels. The CSPRA assesses the legislative and regulatory framework governing public procurement, the institutional framework and management capacity, procurement operations and market practices, and the integrity and transparency of public procurement systems.

3.7 At the project conceptualization stage, ADB gives the project an initial procurement risk rating.

3.8 The PPRA is undertaken during the procurement planning stage and considers the particular risks associated with the project along with more detailed information about the supply market. The Guidance Note on Strategic Procurement Planning discusses the PPRA process further. The PPRA forms part of the Strategic Procurement Plan (SPP).

3.9 At the procurement planning stage, while the borrower is responsible for direct actions, $A D B$ will provide the borrower with relevant information and inputs that can be used by the borrower in developing the procurement plan. ADB will support and contribute to the PPRA as part of preparation of the SPP, in order to identify potential risks associated with the project, assess the level of risks, and propose mitigation measures.

3.10 The CMP is the risk management tool used to ensure that procurement risks applicable at the implementation and contract management stage are effectively managed. The Guidance Note on Contract Management discusses the CMP further.

3.11 The borrower and ADB are responsible for different risk management activities throughout the procurement and need to work together to ensure that risks are identified and managed effectively. While the borrower is directly responsible for such actions, $A D B$ has a fiduciary responsibility to ensure risks are identified and managed within country and sector strategies, and at agency and project levels. Table 2 outlines the responsibilities of ADB and the borrower with respect to risk management. 
Table 2: Responsibilities for Risk Management in the Procurement Cycle

\begin{tabular}{|c|c|c|c|}
\hline \multirow[b]{2}{*}{$\begin{array}{l}\text { Procurement Cycle } \\
\text { Stage }\end{array}$} & \multirow[b]{2}{*}{$\begin{array}{c}\text { Risk Management } \\
\text { Tool }\end{array}$} & \multicolumn{2}{|c|}{ Allocation of Responsibilities } \\
\hline & & $\begin{array}{c}\text { Asian Development } \\
\text { Bank }\end{array}$ & Borrower \\
\hline $\begin{array}{l}\text { Country Partnership } \\
\text { Strategy }\end{array}$ & $\begin{array}{l}\text { Country and Sector/ } \\
\text { Agency Procurement } \\
\text { Risk Assessment }\end{array}$ & Responsible & Consulted \\
\hline $\begin{array}{l}\text { Project } \\
\text { Conceptualization }\end{array}$ & $\begin{array}{l}\text { Concept Stage } \\
\text { Project Procurement } \\
\text { Risk Rating }\end{array}$ & Responsible & Consulted \\
\hline $\begin{array}{l}\text { Procurement } \\
\text { Planning }\end{array}$ & $\begin{array}{l}\text { Project Procurement } \\
\text { Risk Assessment }\end{array}$ & Accountable & Responsible \\
\hline $\begin{array}{l}\text { Implementation } \\
\text { and Contract } \\
\text { Management }\end{array}$ & $\begin{array}{l}\text { Contract } \\
\text { Management Plan }\end{array}$ & Consulted & Responsible \\
\hline
\end{tabular}

Source: Asian Development Bank.

\section{The Procurement Risk Framework Is Continuous and Cascades through the Procurement Cycle}

3.12 Risk management begins at the CPS stage and cascades through the procurement cycle. The outputs from each stage of the procurement risk framework become the inputs for the next stage. Each risk assessment builds on the previous risk framework stage and is supplemented with additional information as the focus of the assessment becomes more targeted toward the project.

3.13 Figure 3 shows that the CSPRA is produced using, among others

(i) inputs of previous CSPRAs;

(ii) literature review (such as reviews based on the Organisation for Economic Co-operation and Development's "Methodology for Assessing Procurement Systems (MAPS)" assessments completed following the Public Expenditure and Financial Accountability framework, and internet search); and

(iii) review of relevant $A D B$ data (including information such as country procurement data, bid evaluation reports, and proactive integrity reviews ${ }^{1}$ by ADB's Office of Anticorruption and Integrity).

3.14 In turn, the initial project procurement risk assessment at the project conceptualization stage uses the CSPRA, and other relevant background information, as an input and results in a procurement risk rating for the project.

1 Proactive Integrity Reviews have replaced Project Procurement Related Reviews. 
3.15 In procurement planning stage, the CSPRA and the concept stage project procurement risk rating are inputs into the PPRA, along with an analysis of the procuring entities strengths and weaknesses, review of the entity's past procurement experience, market assessment, and the proposed packaging and procurement arrangements. The output is the SPP incorporating the PPRA, a project procurement risk register, and a procurement plan.

3.16 The procurement plan and procurement risk register are inputs into the CMP, which is used to manage risk during contract implementation.

3.17 At each stage of the procurement risk framework, the focus narrows, and the risks from the previous stage are filtered for relevance to the current assessment. For instance, in developing the PPRA, the focus narrows from country and sector to agency and project, and only those risks in the CSPRA that impact the project are considered for inclusion in the PPRA.

\section{E. Risks Must Be Managed after Identification}

3.18 An important point emphasized in this guidance note is that simply identifying and assessing risks is not sufficient. To reduce risks to an acceptable level, mitigating measures must be identified that are effective in reducing the risk, and these measures must be implemented. To ensure that the measures are implemented, progress of implementation of the measures needs to be monitored and managed.

3.19 To enable the monitoring and management of mitigation measures, mitigation actions should be documented in a risk assessment document.

3.20 Risk management is not a one-time exercise. Following the initial risk assessment, risks may change or new risks may become apparent. The risk assessment should be updated in response to changed conditions, or new information on risks, and at key points in the procurement process to ensure that risks are effectively managed.

3.21 Figure 5 describes how risks identified in the PPRA and during procurement planning are managed through bidding and contract award to contract implementation.

3.22 Risks identified in the PPRA are managed through the selection of procurement arrangements, e.g., the procurement method, contract structure, contract terms and performance measures, and other mitigating actions. Mitigating measures and action owners should be documented in the PPRA and any associated risk register.

3.23 As the project progresses to the bidding stage, the PPRA and risk register should be reviewed considering any new information coming out of the bid responses that impacts on the risks or mitigation measures. For example, bid clarifications may include changes to specifications and bidder structure not initially anticipated, which may require additional measures to mitigate implementation risks. 
Figure 5: Risk Management through Planning, Bidding, and Implementation

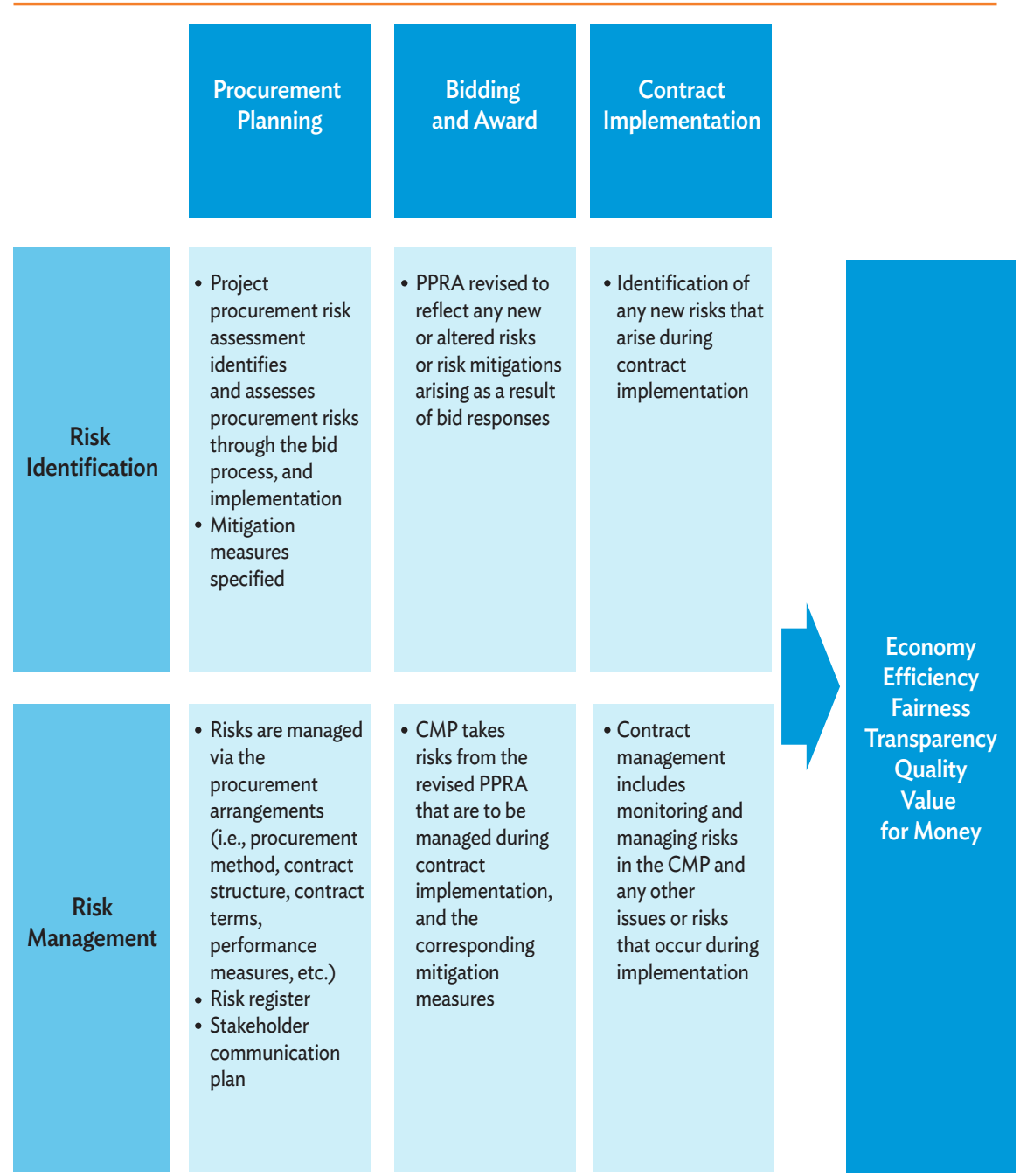

$\mathrm{CMP}=$ contract management plan, $\mathrm{PPRA}=$ project procurement risk assessment.

Source: Asian Development Bank.

3.24 Following bid evaluation and contract award, relevant risks in the updated PPRA should be included in the CMP, along with mitigation actions and action owners. In addition, the CMP should include any other risks (and mitigating actions) relevant to contract implementation that were not included in the PPRA. The risks and mitigating actions in the CMP then need to be monitored by the borrower in the project's monthly and quarterly reports to ensure they are implemented and effective. This can be done by including review of the CMP risk register as a standing item in the contract management meetings with the contractor(s). Any changes to risks or any new risks identified should be reflected in the risk register. 


\section{Risk Assessment and Treatment}

4.1 After risks have been identified, they need to be assessed and treatments considered.

\section{A. Assessing Risks}

4.2 Risk assessment involves the following steps:

(i) estimating the likelihood of the risk being realized,

(ii) estimating the consequence of the risk being realized,

(iii) determining the risk rating, and

(iv) prioritizing risks for treatment.

4.3 The risk likelihood table in Appendix 1 should be used to estimate the likelihood of the risk being realized, ranging from "Rare" to "Almost Certain." A risk likelihood score between 1 and 5 should be determined for the risk corresponding to the likelihood of the risk occurring.

4.4 The risk consequence table in Appendix 1 should be used to estimate the consequence of the risk being realized, ranging from "Insignificant" to "Severe." Impacts are rated according to how they would negatively affect the achievement of ADB's core procurement principles of economy, efficiency, fairness, transparency, quality, and value for money, other procurement objectives stated in ADB procurement principles, or implementation stage impacts such as delay, cost increase, defects or poor quality.

4.5 A risk consequence score between 1 and 5 based on the highest rated impact should be determined for the risk corresponding to the consequence of the risk occurring.

4.6 The risk rating should then be determined using the risk rating matrix in Appendix 1, using the risk likelihood score and the risk consequence score to determine a risk rating. For example, a risk with risk likelihood score of 4 ("Likely") and a risk consequence score of 3 ("Moderate") has a risk rating of "Substantial" (Appendix 1).

4.7 Risks should then be prioritized for treatment. Risks rated "High" and "Substantial" should be given special attention, but treatments to mitigate "Moderate" and "Low" risks should also be considered as appropriate. 


\section{B. Treating Risks}

4.8 Following assessment of the risks, each risk should be treated in one of the four ways described in Figure 6: "avoid," "reduce," "transfer," or "accept."

\section{Figure 6: Risk Treatment Options}

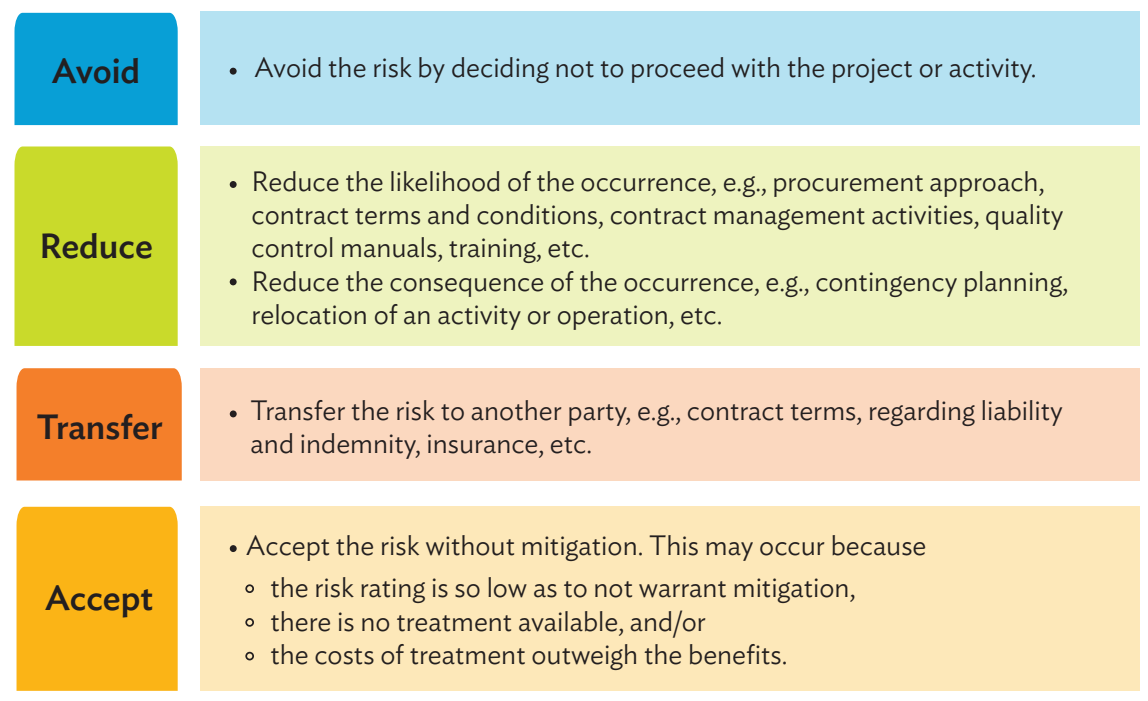

Source: Asian Development Bank.

4.9 In some cases, the only available mitigation measure may be "avoidance." For example, immature national procurement systems may be mitigated by requiring $A D B$ standard documents to be used for $100 \%$ of contracts financed in whole or in part by an ADB loan or grant, or by $A D B$-administered funds.

4.10 Risk mitigation measures should balance their effectiveness for reducing the risk against their costs and effort to implement. Risks rated "High" may warrant additional resources and a specific risk management plan. 


\section{Risk Management in the Procurement Cycle}

\section{A. Country and Sector/Agency Procurement Risk Assessment}

5.1 Normally, prior to preparation of the CPS, ADB performs a CSPRA. The CSPRA gives a broad overview of procurement risks at country and sector/agency level. The level of the assessment will depend on existing knowledge and on an understanding of which sectors/agencies will be involved in projects.

\subsection{The CSPRA is carried out periodically, preferably in advance of CPS} preparation. However, if significant changes that could materially impact risk ratings have been identified, it may be updated at any time during the CPS period.

5.3 The CSPRA gives information for project concept preparation and procurement risk rating during the project conceptualization stage of the procurement cycle. It also gives critical background information for PPRAs developed at the procurement planning stage. Figure 7 describes the process for performing a CSPRA.

5.4 CSPRAs typically begin with a planning phase involving a desktop review of existing country procurement assessments and experience, and the application of a tool to assess country procurement risks. This review is used to develop a field work plan and discussions with the government and other stakeholders.

5.5 The purpose of discussions with the government and other stakeholders is to validate the initial country procurement assessment and to assess sector/agency risks for key sectors. Findings are documented in the CSPRA report.

5.6 Finally, the weaknesses identified in the CSPRA are converted to risks, the risks are assessed, risk treatments are identified, and risks and mitigating measures are documented in a procurement risk assessment and management plan (P-RAMP). The overall country procurement risk is then determined, as is the overall sector risk for each key sector.

5.7 Appendix 2 gives a detailed description of the CSPRA process, including references to tools and templates in Appendix 3 to Appendix 9 of this guidance note.

5.8 There is growing use by donors of OECD's MAPS assessments as an alternative to their own assessments, and there may be cases where a MAPS assessment may exist in place of a CSPRA. ADB might be a participant in such MAPS studies, for example as either a co-author or as a reviewer. 


\section{Figure 7: The Country and Sector/Agency Procurement} Risk Assessment Process

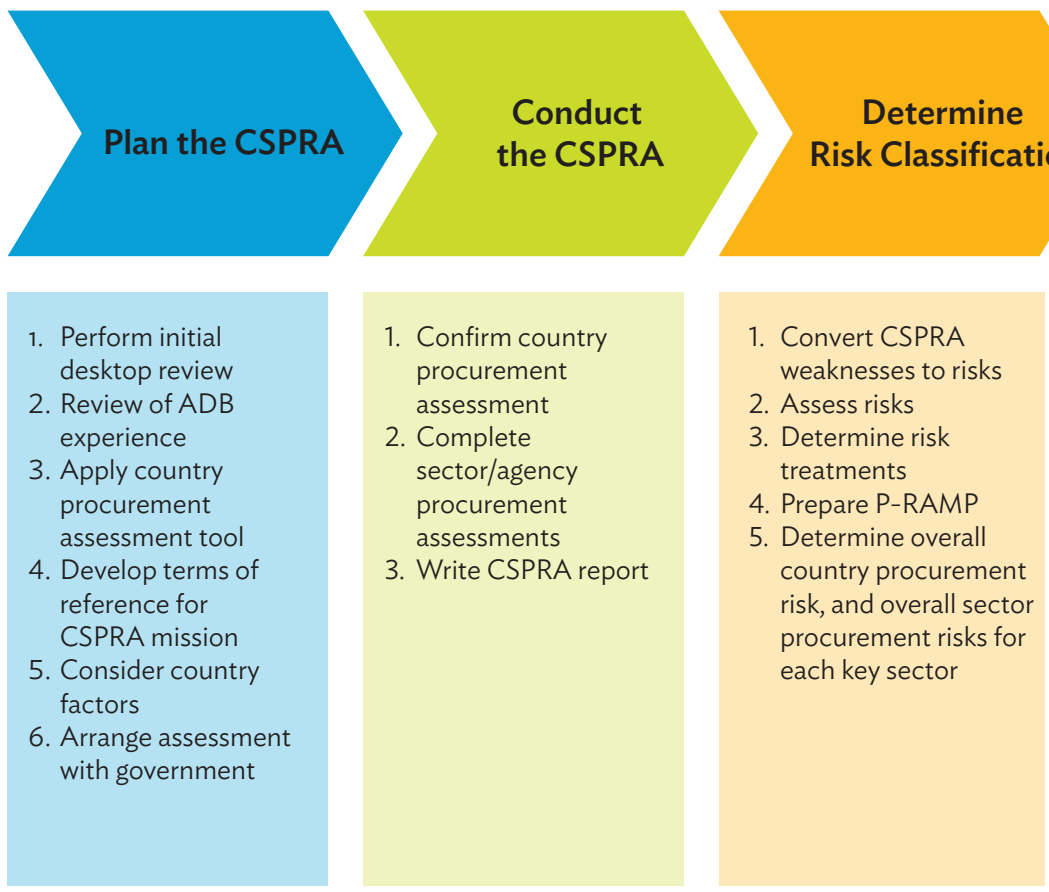

$\mathrm{ADB}=$ Asian Development Bank, CSPRA = country and sector/agency procurement risk assessment, $\mathrm{P}-\mathrm{RAMP}=$ procurement risk assessment and management plan.

Source: Asian Development Bank.

\section{B. Project Conceptualization}

5.9 At the project concept stage, an initial project procurement risk rating is assigned by ADB. The rating is used to guide project preparation and due diligence.

5.10 The project procurement risk rating is a function of (i) the procurement environment in the country and sector (or, where applicable, agency) and (ii) project-specific characteristics.

5.11 The first step is to assess the procurement environment risk based on the country risk and the sector or agency risk applicable to the project, as determined in the CSPRA. The Concept Stage Project Procurement Risk Rating Tool in Appendix 10 is then used to determine the procurement environment risk rating. 


\section{Procurement Planning}

5.12 At procurement planning stage, it will be necessary to assess the procurement and market risks for the project, by developing a PPRA.

5.13 The CSPRA is one input into the PPRA. The information in CSPRA will need to be reviewed for currency and to determine whether it remains valid for the project. If not, the PPRA should reflect the updated situation.

5.14 At this stage, more details will be available concerning the project itself, the precise agencies involved, the nature and scope of the requirements and the contracts envisaged. The PPRA will use this information along with the CSPRA to assess more accurately the procurement risks for the project including market risks. Refer to the Guidance Note on Strategic Procurement Planning for details on project procurement risk assessment.

5.15 The PPRA and the associated procurement risk register are used to develop the procurement plan.

\section{Implementation and Contract Management}

5.16 At the time of contract award, the risks identified in the PPRA and risk register should be reviewed for relevance to the contract implementation stage and relevant risks included in the CMP. In addition, any changes to risks and any newly identified risks, along with associated mitigating actions, should be included in the CMP.

5.17 The CMP and risk register should be updated throughout implementation to reflect any changes to risks or any new risks so that risks are managed effectively until project completion. Refer to the Guidance Note on Contract Management for further detail. 


\section{Resources for Further Review}

6.1 The following ADB guidance notes may be consulted for further information:

(i) Guidance Note on Value for Money,

(ii) Guidance Note on Strategic Procurement Planning, and

(iii) Guidance Note on Contract Management.

6.2 A comparison between CSPRA and MAPS assessments is given in the following Table which highlights the differences in ownership and usage of these tools.

Table 3: A Comparison Between CSPRA and MAPS Assessments

\begin{tabular}{|c|c|c|}
\hline Tool & Advantages & Disadvantages \\
\hline CSPRA & $\begin{array}{l}\text { - Can be carried out according to ADB's } \\
\text { CPS updating schedule } \\
\text { - } \text { Relatively low cost and short schedule } \\
\text { requirement } \\
\text { - Reflects ADB viewpoint, and is for } \\
\text { internal use } \\
\text { - If project modalities such as results-based } \\
\text { lending which rely on country systems are } \\
\text { not under consideration, the assessment } \\
\text { may be a rapid review based only on ADB } \\
\text { data sources such as awards database and } \\
\text { bid evaluation reports. }\end{array}$ & $\begin{array}{l}\text { - Lacks government ownership. } \\
\text { - May have less consultation with } \\
\text { government agencies, and less analysis of } \\
\text { government financed procurement. }\end{array}$ \\
\hline MAPS & $\begin{array}{l}\text { - Full government ownership giving } \\
\text { greatest likelihood recommended actions } \\
\text { are appropriate and are likely to be } \\
\text { implemented } \\
\text { - Principally covers government financed } \\
\text { procurement, but likely also donor } \\
\text { financed procurement. } \\
\text { - Assessments are published hence } \\
\text { contributes to increased transparency and } \\
\text { engagement with stakeholders }\end{array}$ & $\begin{array}{l}\text { - Relatively infrequently used, will not } \\
\text { synchronize with ADB's CPS updating } \\
\text { schedule. } \\
\text { - Is intended for publication hence might be } \\
\text { less candid on risks and shortcomings } \\
\text { - Requires internal approvals including } \\
\text { peer reviews and quality assurance by the } \\
\text { MAPS Secretariat leading to higher cost } \\
\text { and longer schedule requirement } \\
\text { - Challenging to collect and process } \\
\text { data in the absence of a strong public } \\
\text { procurement agency and use of } \\
\text { e-procurement systems }\end{array}$ \\
\hline
\end{tabular}

CSPRA = country and sector/agency procurement risk assessment, MAPS = Methodology for Assessing Procurement Systems.

Source: Asian Development Bank. 


\section{Appendix 1: Risk Assessment Tables}

A1.1 Tables A1.1, A1.2, and A1.3 describe risk likelihood, risk consequence, and the risk rating matrix, respectively. Table A1.4 describes the risk rating key.

Table A1.1: Risk Likelihood

\begin{tabular}{lccc}
\hline Descriptor & Likelihood Score & Description & Indicative Probability \\
\hline Almost certain & 5 & Expected to occur & $>95 \%$ \\
\hline Likely & 4 & Probably will occur & $66 \%-95 \%$ \\
\hline Possible & 3 & $\begin{array}{c}\text { May occur at } \\
\text { some stage }\end{array}$ & $26 \%-65 \%$ \\
\hline Unlikely & 2 & $\begin{array}{c}\text { Would be surprising } \\
\text { if it occurred }\end{array}$ & $5 \%-25 \%$ \\
\hline Rare & 1 & May never occur & $<5 \%$ \\
\hline
\end{tabular}

Source: Asian Development Bank.

Table A1.2: Risk Consequence

\begin{tabular}{lc}
\hline Descriptor & Score \\
\hline Severe & 1 \\
\hline Major & 2 \\
\hline Moderate & 3 \\
\hline Minor & 4 \\
\hline Insignificant & 5 \\
\hline
\end{tabular}

Source: Asian Development Bank. 
Table A1.3: Risk Rating Matrix

\begin{tabular}{|c|c|c|c|c|c|c|c|}
\hline & & & \multicolumn{5}{|c|}{ Risk Consequence } \\
\hline & & & Insignificant & Minor & Moderate & Major & Severe \\
\hline & & & 1 & 2 & 3 & 4 & 5 \\
\hline \multirow{5}{*}{ 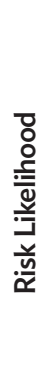 } & $\begin{array}{l}\text { Almost } \\
\text { certain }\end{array}$ & 5 & Moderate & Moderate & Substantial & High & High \\
\hline & Likely & 4 & Moderate & Moderate & Substantial & Substantial & High \\
\hline & Possible & 3 & Low & Moderate & Moderate & Substantial & Substantia \\
\hline & Unlikely & 2 & Low & Low & Moderate & Moderate & Substantia \\
\hline & Rare & 1 & Low & Low & Low & Moderate & Moderate \\
\hline
\end{tabular}

Source: Asian Development Bank.

Table A1.4: Risk Rating Key

\begin{tabular}{l}
\hline High \\
\hline Substantial \\
\hline Moderate \\
Low
\end{tabular}

Source: Asian Development Bank. 


\section{Appendix 2: Country and Sector/Agency Procurement Risk Assessment Process}

A2.1 The country and sector/agency procurement risk assessment (CSPRA) forms part of the thematic and sector analysis undertaken to provide inputs to the preparation of a new country partnership strategy (CPS). It also provides input into project procurement risk classification during the project conceptualization stage of the procurement cycle, and into the development of the project procurement risk assessment (PPRA) at the procurement planning stage. The CSPRA incorporates the requirements of the Second Governance and Anticorruption Action Plan of the Asian Development Bank (ADB).

A2.2 The CSPRA process is described in detail below.

\section{A. Planning the Assessment}

A2.3 ADB (or consultants selected by ADB) will conduct the CSPRA. To plan the assessment and determine the resources required, an initial desktop review is undertaken based on existing procurement assessments, as well as ADB's procurement experience in the country and across key sectors.

\section{Literature Review}

A2.4 The purpose of this step in the process is to identify information relating to public procurement systems. This can include, but is not limited to

(i) CSPRA Reports Carried Out by ADB: ADB may have carried out such assessments (or other similar assessments under different names). These reports may be available from the ADB website or obtained from relevant ADB departments.

(ii) Country Procurement Assessment Reports (CPAR): The CPAR was until 2013 the World Bank's main instrument to assist its member countries in analyzing their procurement policies, organization, and procedures. ADB and other development partners regularly participated in the CPAR exercise. Publicly available CPARs can be found on the World Bank website at http://documents.worldbank.org/ curated/en/docsearch/document-type/540617.

(iii) Organisation for Economic Co-operation and Development, Development Assistance Committee's Methodology for Assessing Procurement Systems (MAPS): Originally created in 2003-2004, the MAPS is intended to provide a common tool to assess the quality and effectiveness of procurement systems. 
(iv) Public Expenditure and Financial Accountability (PEFA): The PEFA Program was founded in 2001 as a multi-donor partnership to assess the condition of country public expenditure, procurement, and financial accountability systems. The PEFA Framework assesses a country's public financial management across 31 indicators, one of which assesses the procurement monitoring, procurement methods, public access to procurement information, and procurement complaints management. Publicly available PEFA assessments can be found on the PEFA website: www.pefa.org.

(v) Internet Search: A variety of bilateral donors and nongovernment organizations regularly assess public procurement systems, including from the perspective of fiduciary risk assessment (i.e., the United Kingdom's Department for International Development, Revenue Watch, etc.). A web search on "procurement fiduciary assessment [country name]" should be performed to identify additional secondary sources of information. The web search should also include e-procurement assessments by various international financial institutions, case studies, presentations and/or research papers relevant to the country.

\section{ADB's Procurement Experience}

A2.5 In addition to the existing assessments of procurement systems, ADB's own experience at the country and sector/agency level should be reviewed:

(i) Country Procurement Data: Historical contract award data of ADB-financed contracts by sector for works, goods, and consulting services with breakdown by contract size, presented using the template in Appendix 3. ADB's contract award database is available for download from ProcDash on the ADB website, although to receive complete data for CSPRA analysis a request should be made by email via the project officer. Contract awards data shows the nature of package sizes typically used, the names and nationalities of key firms winning contracts, and gives an indication of the number of firms having award capacity and experience of various package sizes. If practical, Bid evaluation reports should be reviewed in order to expand on the contract awards information, in particular the number of bids received, the number of responsive bids, details of the qualification criteria used and their suitability, pricing relative to cost estimates, and the presence or absence of negative factors such as abnormally low bidding, or rigged bidding.

(ii) Existing CPS, Country Assistance Program Evaluation, and/or CPS Final Review: The existing CPS and relevant lessons learned should be reviewed to understand better ADB's operations at the country level, and sector and thematic priorities. CPSs should include procurement risk assessment and management plans (P-RAMPs) for the country and several priority sectors. The quality, completeness, and timeliness of the P-RAMPs should be assessed. It may be useful to review any sector road maps prepared in conjunction with the relevant CPS if the contemplated procurement is targeted for such sectors. 
(iii) Office of Anticorruption and Integrity (OAI) Project ProcurementRelated Reviews (PPRRs)': OAl conducts PIRs on ongoing ADBfinanced, administered, and supported projects, to help prevent and detect indicators of integrity violations (i.e. fraud, corruption, collusion, coercion, abuse, conflict of interest, and obstruction). PIR reports contain lessons learned and recommendations on procurement of the reviewed projects. OAl also conducts follow-up reviews to assess implementation progress of the PIR recommendations. Project teams should consult OAI to help identify and analyze and mitigate project procurement risks that may lead to integrity violations. PIR reports can be accessed through https://www.adb.org/who-we-are/integrity/ proactive-integrity-review.

(iv) Reports by ADB's Independent Evaluation Department. In some cases, there may also be reports prepared by ADB's Independent Evaluation Department on the performance of specific ADBfinanced projects in countries that identify procurement-related issues, which may be useful to review as part of the initial assessment.

(v) Country Portfolio Review Mission (CPRM) Report: The purpose of the annual CPRM is to review the overall performance of the portfolio in terms of completing the projects within the approved time and budget, as well as their contributions to sector outcomes and outputs. The CPRM (a) examines country-specific common project implementation problems and constraints, and works out appropriate remedial measures; (b) reviews projects with the executing agencies and proposes solutions for specific problems being encountered; (c) undertakes field visits to selected problem projects to assess the magnitude and effects of identified problems; and (d) agrees on a time-bound action plan with quantifiable monitoring targets to remedy or improve the performance of the portfolio. The CRPM report and the mission's back to office report should be reviewed to identify potential procurement risks.

(vi) Procurement Committee Decisions: Decisions by ADB's Procurement Committee relating to transactions involving executing and implementing agencies in ADB's priority sectors should be reviewed. Key messages and/or findings may indicate possible weaknesses in country and/or sector procurement practices.

(vii) e-Procurement Assessments: ADB initiates assessments of e-procurement systems to determine their acceptability for use in ADB-financed projects. The purpose of the assessment is to ensure compliance of the executing agency's e-procurement system with the multilateral development bank e-procurement guidelines and to ensure that the system complies with ADB's 2017 procurement regulations.

(viii) Project Completion Reports: Project completion reports may contain lessons learned and recommendations about procurement of completed projects.

Project Procurement- Related Reviews (PPRRs) have replaced Project Procurement-Related Reviews (PPRRs). 


\section{Application of the Country Procurement Assessment Tool}

A2.6 The initial country assessment identifies additional information required to complete the CSPRA, and determines the resources required to collect the information and the most appropriate means by which to undertake the field work.

A2.7 The information gathered from literature review and ADB's experience will be used to answer basic questions about a country's public procurement environment in terms of policies, rules, regulations, and institutions at the national level, allowing ADB to identify primary areas in variance with ADB's core procurement principles. The initial country assessment will result in a preliminary score for each of the indicators, an average score for each of the four pillars, and a total average score for the country. The scores will indicate the level of maturity in country procurement systems.

A2.8 The country procurement assessment tool and scoring guide are given in Appendix 4 and assess the legislative and regulatory framework governing public procurement, the institutional framework and management capacity, procurement operations and market practices, and the integrity and transparency of public procurement systems. The tool also allows for an assessment of the gaps in information or where information is dated, and includes some questions pertaining to e-procurement and verification or updating that may be required during the CSPRA.

A2.9 Since there is increasing interest among ADB's developing member countries to use electronic government procurement (e-GP), it is necessary to assess the maturity of e-GP systems in a country as part of the country procurement risk assessment. The assessment of e-GP systems should be undertaken with reference to the Guidance Note on E-Procurement.

\section{Market Risk Assessment}

A2.10 The initial country assessment data will permit a market assessment to be undertaken. For each country and sector/agency assessed, a market assessment needs to be conducted to understand the nature of competition in the sector and identify any challenges or unhealthy patterns in procurement. Recommended tools are a) analysis of ADB's contract award database, and b) bid evaluation report analysis. Example templates that may be used are shown in Appendix 11. Potential risks that may be apparent could include market dominance by one or a small number of firms, collusive behaviour, inability for either foreign or national firms to participate, impact of state owned (or former state owned) enterprises, abnormally low bidding, lack of interest or inability of reputable firms to win bids, use of inappropriate qualification criteria or bidding methods, inability of small and medium enterprises to participate, and other patterns inconsistent with sustainable development of capacity in the supply chain. 


\section{Terms of Reference-Country and Sector/Agency Procurement Risk Assessment}

A2.11 The terms of reference will guide the country and sector/agency assessments. At a minimum, the mission would (i) confirm the findings of the initial country procurement assessment, updating information gaps and narrative description of the country procurement systems, where necessary, including the use of e-GP systems; (ii) assess sector procurement performance; (iii) assess country and sector/agency procurement risks and identify mitigating measures (i.e., prepare the P-RAMP); and (iv) prepare the CSPRA report. Appendix 5 gives an indicative terms of reference.

\section{Country Considerations}

A2.12 When planning a CSPRA, consideration should be given to achieving an acceptable level of comfort in the most cost-effective manner. Depending on the size of the country, the level of decentralization, the geographic focus of ADB's forward program, and/or the size of ADB's program in a given sector, a modified approach to CSPRA may be warranted. For example:

(i) For large developing member countries, particularly when ADB's program has a geographic concentration or with a high degree of decentralized government services (including procurement), consideration should be given to subnational procurement assessments.

(ii) For smaller programs, with limited loan or grant financing, it may be more appropriate to conduct the sector/agency procurement assessment as part of project processing.

(iii) For larger programs, or with dominant sector agencies, the sector assessments may be best conducted at the agency level, rather than aggregated at the sector level.

(iv) If ADB loan- and grant-financed operations are focused on a subsector, then it may be more appropriate to conduct the sector/agency assessment at the level of that subsector.

(v) Fragile or conflict-affected situations require specific consideration, not only with respect to how to assess country, sector, and/or agency procurement risks, but also with how to identify opportunities for providing additional flexibility that may be needed to enable effective project implementation. ${ }^{2}$

2 For further information, refer to: (i) the Guidance Note on Fragile, Conflict-Affected, and Emergency Situations, and (ii) ADB. 2012. Working Differently in Fragile and Conflict-Affected Situations-A Staff Handbook. Manila. 
A2.13 The terms of reference should make clear the required scope regarding the sectors and agencies to be covered, and whether either (a) a rapid assessment or updating of a previous assessment based on review of ADB data sources, or (b) a full assessment of country systems to evaluate potential use of country systems in ADB financed procurement will be undertaken. The former may be undertaken principally with ADB data sources (contract awards database, bid evaluation reports, interview with $A D B$ relevant staff), whereas the latter requires access to data on government financed procurement and consultation with government agencies in each sector.

\section{Communicating with the Government}

A2.14 Once the planning has been completed, the ADB team should arrange for the assessment with the concerned client government and key sector agencies. Consideration should also be given as to the level of involvement of government counterparts and other development partners.

\section{B. Conducting the Assessment: Confirm the Country Procurement Assessment and Complete the Sector/Agency Procurement Assessments}

A2.15 The in-country assessment will involve discussions with relevant stakeholders, including the government, development partners, pertinent local industries, and civil society organizations that are active in ADB's key sectors. The in-country assessment will update and verify the information gathered during the desk review and assess sector/agency procurement performance.

A2.16 Appendix 6 gives the sector/agency questionnaire and scoring guide. The tool should be applied to each of the sectors assessed to determine the degree of variability in procurement capacity across sectors and as compared to the expectations embodied in the national procurement systems. The sector assessment template includes a questionnaire that should be used when conducting interviews and a scoring guide. The sector score should reflect the average score across agencies. The questionnaire should be used by the assessor. It is not designed as a self-assessment tool.

A2.17 The results are analyzed and form the basis for completing the narrative assessment of the country and sector/agency procurement systems. Appendix 7 gives an annotated outline for the CSPRA report.

A2.18 For the country, and for each priority sector assessed, the report should cover the description of the procurement systems (at the country level) and procurement practices (at the sector or agency level); the strengths of the procurement systems or practices (generally these would include areas with a score of 2 or 3 on average) and any weaknesses identified (generally these areas would have a score of 0 or 1 on average). 


\section{Determining the Risk Classification}

A2.19 The potential weaknesses in country procurement systems and sector/ agency procurement practices, and market risks identified in the CSPRA are further examined to determine the extent to which these weaknesses pose risks to projects financed in whole or in part by an ADB loan or grant, or by ADB-administered funds.

A2.20 The first step is to identify the potential risks that have emerged from the assessments. Appendix 8 gives a list of indicative procurement risks at the country and sector/agency level.

A2.21 Weaknesses identified in the CSPRA may require the gathering of additional information to determine the root cause of the weakness and how it may result in a risk. Table $\mathrm{A} 2$ gives an example of how to convert an identified weakness into a potential risk.

\section{Table A2: Example of How a Procurement Weakness May Convert to a Risk}

\begin{tabular}{ll}
\hline Weakness & $\begin{array}{l}\text { Key sector agencies use direct selection as the default } \\
\text { procurement method }\end{array}$ \\
\hline Risk & $\begin{array}{l}\text { Bidders without adequate qualifications and capacity } \\
\text { are selected }\end{array}$ \\
\hline Potential Impact & $\begin{array}{l}\text { Lack of transparency, procurement delays, increased prices, } \\
\text { reduced quality, reduced life span of assets procured, } \\
\text { reputational risks }\end{array}$ \\
\hline
\end{tabular}

Source: Asian Development Bank.

A2.22 Once risks have been identified, it is necessary to assess them to determine whether the risk is likely to occur and, if it were to occur, the likely impact it could have on ADB loan and grant operations. Risks must be prioritized according to risk rating and treatments identified to mitigate and manage them. Section IV of this guidance note gives more detail on how to assess risks and develop treatment options.

A2.23 If an e-procurement system is used in the country (or by specific executing agencies), the risk assessment should denote if this has helped in the management of procurement risks. The current scope and plans to further improve the e-procurement system should be clearly mentioned. The report should also mention risks related to e-procurement use, if any, and how they are to be mitigated. 
A2.24 Once the risks have been identified and categorized, and mitigation measures identified, the P-RAMP is prepared. The risks should be disaggregated between the country level and the specific sector/agency level, with overall risk ratings given for both the country and individual sectors assessed. Appendix 9 gives the standard template.

A2.25 The final step of risk assessment is to determine the overall country procurement risk and the overall procurement risk in each of the core sectors/agencies reviewed. The overall risks should be rated as high, substantial, moderate, or low and are reflected in the P-RAMP. In considering the overall rating, the assessor considers the cumulative impact of the risks identified and the likelihood of that impact occurring. This requires professional judgment and should not simply be a straight average of the individual risk ratings shown in the P-RAMP. 


\section{Appendix 3: Country Procurement Data Sheet}

A3.1 Data from ADB's contract awards database at ProcDash on the ADB website (additional data fields can be requested via the project officer) should be analysed and presented in the country procurement data sheet. World Bank also has a public database of contract awards for download and analysis. ${ }^{2}$

\section{COUNTRY NAME:}

DATA AS AT: [most recent quarter end data]

\begin{tabular}{|c|c|c|c|c|c|c|c|c|}
\hline \multirow[b]{2}{*}{ Contracts } & \multicolumn{3}{|c|}{ Total Contracts } & \multicolumn{5}{|c|}{ Number of Contracts Whose Value is } \\
\hline & Number & Value & $\begin{array}{c}\text { Average } \\
\text { Contract } \\
\text { Value }\end{array}$ & $<1,000,000$ & $\begin{array}{l}1,000,000- \\
2,000,000\end{array}$ & $\begin{array}{l}2,000,000- \\
5,000,000\end{array}$ & $\begin{array}{l}5,000,000- \\
10,000,000\end{array}$ & $>10,000,000$ \\
\hline \multicolumn{9}{|l|}{$\begin{array}{l}\text { Total } \\
\text { Country }\end{array}$} \\
\hline \multicolumn{9}{|l|}{ By Sector: } \\
\hline \multicolumn{9}{|l|}{ ANR } \\
\hline \multicolumn{9}{|l|}{ Education } \\
\hline \multicolumn{9}{|l|}{ Energy } \\
\hline \multicolumn{9}{|l|}{ Health } \\
\hline \multicolumn{9}{|l|}{$\begin{array}{l}\text { Industry/ } \\
\text { Trade }\end{array}$} \\
\hline \multicolumn{9}{|l|}{ PSM } \\
\hline \multicolumn{9}{|l|}{ Transport } \\
\hline $\begin{array}{l}\text { Water/ } \\
\text { Urban }\end{array}$ & & & & & & & & \\
\hline
\end{tabular}

1 Operational Procurement Database (2016-2021). https://data.adb.org/dataset/operationalprocurement-database. Suggest select "Procurement by Nationality, (XLSX)". The global database is downloaded and can be filtered in Excel to select the required project country. Additional data fields should be requested for (a) total contract amount; (b) procurement method i.e. OCB international advertising, OCB national advertising, Shopping; (c) date of invitation for bids date (in order to calculate elapsed time); (d) cost estimate.

2 World Bank Finances. https://finances.worldbank.org/Procurement/Major-Contract-Awards/ kdui-wcs3. Suggest select export, then choose "CSV for Excel". The global database is downloaded and can be filtered in Excel to select the required project country. 


\begin{tabular}{|c|c|c|c|c|c|c|c|c|}
\hline \multirow[b]{2}{*}{ Contracts } & \multicolumn{3}{|c|}{ Total Goods Contracts } & \multicolumn{5}{|c|}{ Number of Contracts Whose Value is } \\
\hline & Number & Value & $\begin{array}{c}\text { Average } \\
\text { Contract } \\
\text { Value }\end{array}$ & $<1,000,000$ & $\begin{array}{l}1,000,000- \\
2,000,000\end{array}$ & $\begin{array}{c}2,000,000- \\
5,000,000\end{array}$ & $\begin{array}{l}5,000,000- \\
10,000,000\end{array}$ & $>10,000,000$ \\
\hline \multicolumn{9}{|l|}{\begin{tabular}{|l} 
Total \\
Country
\end{tabular}} \\
\hline \multicolumn{9}{|l|}{ By Sector: } \\
\hline \multicolumn{9}{|l|}{ ANR } \\
\hline \multicolumn{9}{|l|}{ Education } \\
\hline \multicolumn{9}{|l|}{ Energy } \\
\hline \multicolumn{9}{|l|}{ Health } \\
\hline \multicolumn{9}{|l|}{$\begin{array}{l}\text { Industry/ } \\
\text { Trade }\end{array}$} \\
\hline \multicolumn{9}{|l|}{ PSM } \\
\hline \multicolumn{9}{|l|}{ Transport } \\
\hline $\begin{array}{l}\text { Water/ } \\
\text { Urban }\end{array}$ & & & & & & & & \\
\hline
\end{tabular}

\begin{tabular}{|c|c|c|c|c|c|c|c|c|}
\hline \multirow[b]{2}{*}{ Contracts } & \multicolumn{3}{|c|}{ Total Works Contracts } & \multicolumn{5}{|c|}{ Number of Works Contracts Whose Value is } \\
\hline & Number & Value & $\begin{array}{c}\text { Average } \\
\text { Contract } \\
\text { Value }\end{array}$ & $<1,000,000$ & $\begin{array}{l}1,000,000- \\
2,000,000\end{array}$ & $\begin{array}{c}2,000,000- \\
5,000,000\end{array}$ & $\begin{array}{l}5,000,000- \\
10,000,000\end{array}$ & $>10,000,000$ \\
\hline \multicolumn{9}{|l|}{$\begin{array}{l}\text { Total } \\
\text { Country }\end{array}$} \\
\hline \multicolumn{9}{|l|}{ By Sector: } \\
\hline \multicolumn{9}{|l|}{ ANR } \\
\hline \multicolumn{9}{|l|}{ Education } \\
\hline \multicolumn{9}{|l|}{ Energy } \\
\hline \multicolumn{9}{|l|}{ Health } \\
\hline \multicolumn{9}{|l|}{$\begin{array}{l}\text { Industry/ } \\
\text { Trade }\end{array}$} \\
\hline \multicolumn{9}{|l|}{ PSM } \\
\hline \multicolumn{9}{|l|}{ Transport } \\
\hline $\begin{array}{l}\text { Water/ } \\
\text { Urban }\end{array}$ & & & & & & & & \\
\hline
\end{tabular}




\begin{tabular}{|c|c|c|c|c|c|c|c|c|}
\hline \multirow[b]{2}{*}{ Contracts } & \multicolumn{3}{|c|}{ Total Consulting Contracts } & \multicolumn{5}{|c|}{ Number of Consulting Contracts Whose Value is } \\
\hline & Number & Value & $\begin{array}{c}\text { Average } \\
\text { Contract } \\
\text { Value }\end{array}$ & $<1,000,000$ & $\begin{array}{l}1,000,000- \\
2,000,000\end{array}$ & $\begin{array}{c}2,000,000- \\
5,000,000\end{array}$ & $\begin{array}{l}5,000,000- \\
10,000,000\end{array}$ & $>10,000,000$ \\
\hline \multicolumn{9}{|l|}{$\begin{array}{l}\text { Total } \\
\text { Country }\end{array}$} \\
\hline \multicolumn{9}{|l|}{ By Sector: } \\
\hline \multicolumn{9}{|l|}{ ANR } \\
\hline \multicolumn{9}{|l|}{ Education } \\
\hline \multicolumn{9}{|l|}{ Energy } \\
\hline \multicolumn{9}{|l|}{ Health } \\
\hline \multicolumn{9}{|l|}{$\begin{array}{l}\text { Industry/ } \\
\text { Trade }\end{array}$} \\
\hline \multicolumn{9}{|l|}{ PSM } \\
\hline \multicolumn{9}{|l|}{ Transport } \\
\hline $\begin{array}{l}\text { Water/ } \\
\text { Urban }\end{array}$ & & & & & & & & \\
\hline
\end{tabular}

\section{Procurement Methods}

\begin{tabular}{|c|c|c|c|c|c|c|c|}
\hline & \multicolumn{7}{|c|}{ Value of Contracts } \\
\hline & $\begin{array}{c}\text { OCB Works } \\
\text { International } \\
\text { advertising }\end{array}$ & $\begin{array}{c}\text { OCB } \\
\text { Works } \\
\text { National } \\
\text { advertising }\end{array}$ & $\begin{array}{c}\text { OCB Goods } \\
\text { International } \\
\text { advertising }\end{array}$ & $\begin{array}{c}\text { OCB } \\
\text { Goods } \\
\text { National } \\
\text { advertising }\end{array}$ & $\begin{array}{l}\text { Request } \\
\text { for } \\
\text { Quotation }\end{array}$ & Direct/Sole & Total \\
\hline \multicolumn{8}{|l|}{ Country } \\
\hline \multicolumn{8}{|c|}{ By Sector: } \\
\hline \multicolumn{8}{|l|}{ ANR } \\
\hline \multicolumn{8}{|c|}{ Education } \\
\hline \multicolumn{8}{|l|}{ Energy } \\
\hline \multicolumn{8}{|l|}{ Health } \\
\hline \multicolumn{8}{|c|}{$\begin{array}{l}\text { Industry/ } \\
\text { Trade }\end{array}$} \\
\hline \multicolumn{8}{|l|}{ PSM } \\
\hline \multicolumn{8}{|c|}{ Transport } \\
\hline $\begin{array}{l}\text { Water/ } \\
\text { Urban }\end{array}$ & & & & & & & \\
\hline
\end{tabular}


Contract Variations

\begin{tabular}{|c|c|c|c|c|c|c|c|c|}
\hline \multirow[b]{2}{*}{$\begin{array}{l}\text { Active } \\
\text { Contracts }\end{array}$} & \multicolumn{2}{|c|}{$\begin{array}{l}\text { Total Contracts } \\
\text { Variations }\end{array}$} & \multicolumn{3}{|c|}{$\begin{array}{l}\text { Original Contract } \\
\text { Plus All Variations }\end{array}$} & \multicolumn{3}{|c|}{$\begin{array}{c}\text { Contracts with Value }+/-10 \% \text { PC } \\
\text { Threshold }\end{array}$} \\
\hline & Number & Value & Number & Value & $\begin{array}{l}\% \text { Active } \\
\text { Portfolio }\end{array}$ & Number & Value & $\begin{array}{l}\text { \% Active } \\
\text { Portfolio }\end{array}$ \\
\hline \multicolumn{9}{|l|}{$\begin{array}{l}\text { Total } \\
\text { Country }\end{array}$} \\
\hline \multicolumn{9}{|l|}{ By Sector: } \\
\hline \multicolumn{9}{|l|}{ ANR } \\
\hline \multicolumn{9}{|l|}{ Education } \\
\hline \multicolumn{9}{|l|}{ Energy } \\
\hline \multicolumn{9}{|l|}{ Health } \\
\hline \multicolumn{9}{|l|}{$\begin{array}{l}\text { Industry/ } \\
\text { Trade }\end{array}$} \\
\hline \multicolumn{9}{|l|}{ PSM } \\
\hline \multicolumn{9}{|l|}{ Transport } \\
\hline $\begin{array}{l}\text { Water/ } \\
\text { Urban }\end{array}$ & & & & & & & & \\
\hline
\end{tabular}

\section{Efficiency}

\begin{tabular}{|l|l|l|l|}
\hline \multirow{2}{*}{} & \multicolumn{3}{|c|}{ Elapsed Time to award contract in days ${ }^{\mathrm{a}}$} \\
\cline { 2 - 4 } & $\begin{array}{c}\text { OCB-International } \\
\text { advertising }\end{array}$ & $\begin{array}{c}\text { OCB-National } \\
\text { advertising }\end{array}$ & \multicolumn{1}{|c|}{ Shopping } \\
\hline Total Country & & & \\
\hline By Sector: & & & \\
\hline ANR & & & \\
\hline Education & & & \\
\hline Energy & & & \\
\hline Health & & & \\
\hline Industry/Trade & & & \\
\hline PSM & & & \\
\hline Transport & & & \\
\hline Water/Urban & & & \\
\hline
\end{tabular}


32 Appendix 3

\section{Competition}

\begin{tabular}{|l|l|c|c|c|}
\hline \multirow{2}{*}{ COUNTRY } & \multicolumn{2}{|c|}{ GOODS } & \multicolumn{2}{c|}{ WORKS } \\
\cline { 2 - 5 } & $\begin{array}{c}\text { Average of } \\
\text { 3 largest contracts } \\
\text { awarded to } \\
\text { National Firms }\end{array}$ & $\begin{array}{c}\text { Average of } \\
\text { 3 smallest contracts } \\
\text { awarded to } \\
\text { Foreign Firms }\end{array}$ & $\begin{array}{c}\text { Average of } \\
\text { 3 largest contracts } \\
\text { awarded to } \\
\text { National Firms }\end{array}$ & $\begin{array}{c}\text { Average of } \\
\text { 3 smallest contracts } \\
\text { awarded to } \\
\text { Foreign Firms }\end{array}$ \\
\hline Total Country & & & & \\
\hline By Sector: & & & & \\
\hline ANR & & & & \\
\hline Education & & & & \\
\hline Energy & & & & \\
\hline Health & & & & \\
\hline Industry/Trade & & & \\
\hline PSM & & & \\
\hline Transport & & & \\
\hline Water/Urban & & & \\
\hline
\end{tabular}

ANR = agriculture, natural resources, and rural development; PSM = public sector management.

a From issue of invitation for bids to award of contract.

Source: Asian Development Bank. 


\section{Appendix 4: Country Procurement Assessment Tool}

A4.1 Table A4.1 describes the country procurement assessment tool. Table A4.2 describes the scoring guide for this tool.

Table A4.1: Country Procurement Assessment Tool

\begin{tabular}{lll}
\hline Indicators & \multicolumn{1}{c}{$\begin{array}{c}\text { Score } \\
\text { [Average of } \\
\text { 1. Legislative and Regulatory Framework }\end{array}$} & $\begin{array}{l}\text { Narrative/Verification or } \\
\text { Clarification Required }\end{array}$ \\
\hline $\begin{array}{l}1.1 \text { Is there a comprehensive public procurement } \\
\text { law, with supporting regulations, standard } \\
\text { bidding documents, and operational manuals } \\
\text { or guides? }\end{array}$ & $\begin{array}{l}\text { [The assessor should give } \\
\text { a narrative response and } \\
\text { determine whether } \\
\text { additional information or } \\
\text { verification is required.] }\end{array}$ \\
\hline
\end{tabular}

1.2 Does the legal framework make open competitive tendering the default method of procurement, with clarity as to when other less competitive methods can be used?

1.3 Does the legal framework support nondiscriminatory participation (i.e., all eligible bidders can participate, and that registration, if required, does not constitute a barrier to participation in tenders), and transparent tender processes (including advertisement, tender documentation, tender evaluation, complaints mechanism)?

1.4 Are there restrictions or preferences on the nationality of bidders, consulting firms and/or the origin of goods, works, and services?

1.5 Does the legal and regulatory framework enable the use of an e-procurement system?

$\begin{array}{ll}\text { 2. Institutional Framework and } & \text { [Average of } \\ \text { Management Capacity } & 2.1-2.6]\end{array}$

2.1 Is the procurement cycle required to be tied to an annual budgeting cycle (i.e., can a procurement activity commence only when budget has been duly appropriated for it)? 
Table A4.1 continued

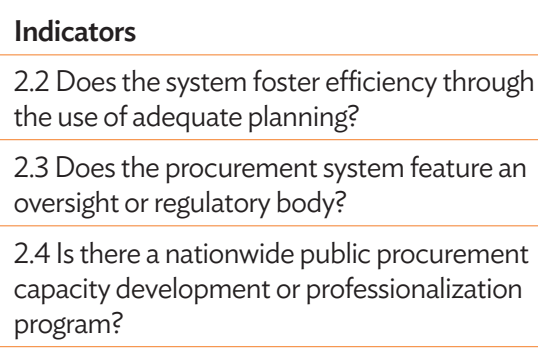

2.5 Is there a dedicated group institutionalized for e-procurement in the public procurement department?

2.6 If an e-procurement system is used, is there a structured approach to capacity building and analyzing its effective use?

\begin{tabular}{ll} 
3. Procurement Operations & {$[$ Average of } \\
and Market Practices & $3.1-3.5]$ \\
\hline
\end{tabular}

3.1 Is the private sector competitive, well organized, and able to access the market?

3.2 Do measures exist to ensure the adequacy and accuracy of cost estimates before bidding, and to manage contract price variations?

3.3 Is the private sector able to access and participate in e-procurement?

3.4 Do commercial bank practices support the private sector industry and procurement operations adequately?

3.5 Is there a mechanism to receive and handle observations, complaints, and protests?

\section{Integrity and Transparency of the Public Procurement System \\ [Average of \\ 4.1-4.4]}

4.1 Is there a formal internal control and audit framework?

4.2 Is information pertaining to public procurement easy to find, comprehensive, and relevant?

4.3 Can bidders and other stakeholders easily access procurement information through the e-procurement system?

4.4 Does the country have ethics and anticorruption measures in place?

Average Score for the Country

\subsection{Does the procurement system feature an}


Table A4.2: Country Procurement Assessment Tool Scoring Guide

\begin{tabular}{l}
\hline Indicators/Questions \\
\hline 1. Legislative and Regulatory F \\
\hline 1.1 Is there a comprehensive \\
public procurement law, \\
with supporting regulations, \\
standard bidding documents, \\
and operational manuals or \\
guides?
\end{tabular}

1.2 Does the legal framework make open competitive tendering the default method of procurement, with clarity as to when other less competitive methods can be used?

\section{Scoring Guide}

3 - These documents exist and are consistent with each other.

2 - Procurement law exists, but not all other documents are available, or there are inconsistencies among the documents. 1 - Procurement law exists, but limited supporting regulations, standard bidding documents, or operational guidance exist. 0 - There is no public procurement law.

3 - The legal framework meets all the following conditions: (a) (a) Allowable procurement methods are established unambiguously at an appropriate hierarchical level, along with the associated conditions under which each method may be used, including a requirement for approval by an official that is held accountable.

(b) Competitive procurement is the default method of public procurement.

(c) Fractioning of contracts to limit competition is prohibited.

(d) Appropriate standards for international competitive tendering are specified and are consistent with international standards.

2 - The legal framework meets the conditions of (a) and (b), plus one of the remaining conditions.

1 - The legal framework meets the conditions of (a) and (b) only.

0 - The legal framework fails to substantially comply with any three of the conditions (a) through (d).

1.3 Does the legal framework support nondiscriminatory participation (i.e., all eligible bidders are allowed to participate, and that registration, if required, does not constitute a barrier to participation in tenders), and transparent tender processes (including advertisement, tender documentation, tender evaluation, complaints mechanism)?

1.4 Are there restrictions or preferences on the nationality of bidders, consulting firms and/or the origin of goods, works, and services?
3 - Legal framework supports nondiscriminatory participation, and tender processes in line with international good practice, including public advertising of business opportunities with sufficient time for bidders to obtain documents and respond to the advertisement, and an effective complaints mechanism.

2 - Legal framework generally supports nondiscriminatory participation, and tender processes are generally transparent, though some weaknesses exist (e.g., lack of complaints mechanism, some barriers to participation, etc.).

1 - Legal framework generally supports nondiscriminatory participation, but weaknesses exist that could serve to limit participation.

0 - Legal framework lacks nondiscriminatory participation and displays insufficient transparency of tender processes.

3 - There is no nationality restriction or domestic preference scheme.

2 - There is no nationality restriction, but there is a domestic preference scheme.

1 - There is a limited nationality restriction (i.e., subject to clearly defined exceptions), and/or a domestic preference scheme is adopted with unreasonably high rates.

0 - Procurement is solely limited to national firms or individuals and/or origin of goods, works, and services. 
Table A4. 2 continued

\begin{tabular}{|c|c|}
\hline Indicators/Questions & Scoring Guide \\
\hline $\begin{array}{l}1.5 \text { Does the legal and } \\
\text { regulatory framework enable } \\
\text { the use of an e-procurement } \\
\text { system? }\end{array}$ & $\begin{array}{l}\text { 3- National public procurement law requires the use of } \\
\text { e-procurement by all of government agencies; the rules for } \\
\text { e-procurement implementation are included in the law, } \\
\text { and electronic and paper bidding documents are considered } \\
\text { equally valid. } \\
2 \text { - National public procurement law requires the use of } \\
\text { e-procurement at the national level, but rules for e-procurement } \\
\text { implementation are not completed, and electronic and paper } \\
\text { bidding documents may or may not be considered equally valid. } \\
1 \text { - National public procurement law does not require } \\
\text { use of e-procurement, but some government agencies use } \\
\text { e-procurement; the rules for e-procurement implementation are } \\
\text { not part of the law. } \\
0 \text { - National public procurement law does not require use of } \\
\text { e-procurement; no government agencies use e-procurement. }\end{array}$ \\
\hline
\end{tabular}

2. Institutional Framework and Management Capacity

2.1 Is the procurement cycle required to be tied to an annual budgeting cycle (i.e., can a procurement activity commence only when budget has been duly appropriated for it)?
3 - The procurement cycle is adequately linked with the annual budget cycle, with provision for advance procurement as necessary. 2 - A procurement activity may start up to, but excluding, contract award until the budget has been duly appropriated. 1 - The law provides for procurement and budget cycles, but these are not adequately linked (i.e., a procurement activity may commence and be concluded even without a duly appropriated budget).

0 - No clear procurement and budget cycles are established by law.

2.2 Does the system foster efficiency through the use of adequate planning?

3 - There is a regular planning exercise under the law that starts with the preparation of multiyear operating plans, followed by annual procurement plans of associated expenditures, and culminating in the annual budget formulation.

2 - The law provides for multiyear operating plans and annual procurement plans that are independent of budget appropriation, but these are at least required to reflect forward budget estimates. 1 - Annual procurement plans are required, but the law does not provide for the preparation of multiyear or annual operating plans.

0 - The law does not require the preparation of procurement plans.

3 - There is a regulatory body, or functions are clearly

2.3 Does the procurement system feature an oversight or regulatory body? assigned to unit(s) within government, which is specified in the legal framework; the regulatory body is at an adequate level in government and financing is secured by the legal or regulatory framework.

2 - There is a regulatory body or functional designation to unit(s) within government but this is not part of the legal or regulatory framework; and/or the body is at an adequate level, but financing is subject to administrative decisions and can be changed easily. 
Table A4. 2 continued

\begin{tabular}{ll}
\hline Indicators/Questions & \multicolumn{1}{c}{ Scoring Guide } \\
\hline & 1- Only partial responsibilities of a regulatory body are assigned, \\
or the level of the body is too low or financing is inadequate for \\
proper discharge of its responsibilities. \\
0-There is no body, or the body is too low with no independence \\
to perform its obligations.
\end{tabular}

\section{Procurement Operations and Market Practices}

3.1 Is the private sector competitive, well organized, and able to access the market?
3 - The private sector is competitive, well organized (e.g., professional associations exist), and able to participate in competition for public procurement contracts.

2 - There is a reasonably well-functioning private sector, but competition for large contracts is concentrated in a relatively small number of firms.

1 - The private sector is relatively weak and/or competition is limited owing to monopolistic or oligopolistic features in the market.

0 - The private sector is not well organized and lacks capacity and access to information for participation in the public procurement market. 
Table A4. 2 continued

\begin{tabular}{|c|c|}
\hline Indicators/Questions & Scoring Guide \\
\hline $\begin{array}{l}3.2 \text { Do measures exist to } \\
\text { ensure the adequacy and } \\
\text { accuracy of cost estimates } \\
\text { before bidding, and to manage } \\
\text { contract price variations? }\end{array}$ & $\begin{array}{l}3 \text { - Detailed measures exist along with clear guidelines to check } \\
\text { the adequacy and accuracy of cost estimates and proposed } \\
\text { variations. } \\
2 \text { - Some measures exist, but these do not provide sufficient } \\
\text { guidance. } \\
1 \text { - There is a requirement to check the adequacy and accuracy } \\
\text { of cost estimates and proposed variations, but no measure } \\
\text { (indicator) or guidance provided. } \\
0 \text { - There are no measures (indicators) and/or requirements. }\end{array}$ \\
\hline $\begin{array}{l}3.3 \text { Is the private sector able } \\
\text { to access and participate in } \\
\text { e-procurement? }\end{array}$ & $\begin{array}{l}3 \text { - The private sector is able to access all national public } \\
\text { procurement information and policies and transact though the } \\
\text { system (register electronically in the registry system, submit bids or } \\
\text { proposals online, use credit cards and other payment modes, and } \\
\text { receive payments through the system); foreign bidders are able to } \\
\text { participate. There is adequate help desk support. } \\
2 \text { - The private sector is able to access most of the national public } \\
\text { procurement information and policies and partly transact through } \\
\text { the system (limited to 2-3 functionalities only). Foreign bidders } \\
\text { are not able to participate. Limited help desk support. } \\
1 \text { - The private sector is able to access only a limited amount of } \\
\text { procurement information and policies, but transacts manually. No } \\
\text { help desk. } \\
0 \text { - The private sector is not able to access and participate in } \\
\text { e-procurement. }\end{array}$ \\
\hline
\end{tabular}

3.4 Do commercial bank practices support the private sector industry and procurement operations adequately?
3 - Bank branches have adequate powers to issue bid securities, advance payment securities, and performance securities without major delays and reference to headquarters. Private sector is generally able to access bank credit facilities without much hindrance.

2 - Only some banks or branches are generally geared to issue such securities expeditiously and grant credit facilities without much hindrance to all competitive firms.

1 - Only some banks or branches are generally geared to issue such securities expeditiously and grant credit facilities without much hindrance, but they do so after reference to headquarters and only to large- and medium-sized firms.

0 - No bank can issue securities and credit facilities without reference to headquarters. Small firms cannot obtain such facilities at all.

3 - There is an independent review body that has clear authority and is bound by reasonable procedures and timelines.

2 - There is an independent review body, but the mechanisms for decision making and enforcement are unclear or cumbersome.

1 - There is a formal review mechanism, but there is no independent review body.

0 - There is no formal review mechanism. 
Table A4. 2 continued

Indicators/Questions Scoring Guide

\section{Integrity and Transparency of the Public Procurement System}

4.1 Is there a formal internal control and audit framework?
3 - This is provided by law, and there are adequate internal control and audit mechanisms and institutions to oversee the procurement function.

2 - This provided by law, and there are implementing guidelines, but the mechanisms and institutions are not adequately established.

1 - This is provided by law, but there are no implementing guidelines and no mechanisms and institutions.

0 - The law does not provide for a formal internal audit and control system.

4.2 Is information pertaining to public procurement easy to find, comprehensive, and relevant?

3 - Information on procurement is easily accessible in media of wide circulation and availability. The information provided is centralized in a common place and is relevant and complete. 2 - Information is posted in media not readily and widely accessible or not user friendly for the public at large, or is difficult to understand to the average user, or essential information is lacking. 1 - Information is difficult to get and very limited in content and availability.

0 - There is no public information system as such and it is generally up to the procuring entity to publish information.

4.3 Can bidders and other stakeholders easily access procurement information through the e-procurement system?

3 - The private sector and civil society are able to access national procurement information through the system.

2 - The private sector and civil society are able to access some national procurement information through the system.

1 - The private sector and civil society are able to access a limited amount of national procurement information through the system. 0 - The private sector and civil society are not able to access national procurement information through the system.

4.4 Does the country have ethics and anticorruption measures in place?
3 - Tender documents include adequate provisions on integrity violations; integrity violation in procurement is defined; specific measures are in place and implemented related to conflict of interest and other integrity violations (e.g. fraud, collusion, corruption, coercion); responsibilities and consequences for those found guilty of fraud, corruption or other integrity violations are clearly described; ample evidence of enforcement; special measures are in place for reporting, detection and prevention of corruption associated with procurement.

2 - Tender documents generally cover fraud and corruption but without consistency; conflict of interest is defined and highlighted in relevant regulations; no specific definition of fraud or corruption in procurement; some evidence of enforcement; government anticorruption program does not include special measures related to public procurement. 
Table A4. 2 continued

\begin{tabular}{ll}
\hline Indicators/Questions & \multicolumn{1}{c}{ Scoring Guide } \\
\hline $\begin{array}{l}\text { 4.4 Does the country have } \\
\text { ethics and anticorruption }\end{array}$ & $\begin{array}{l}\text { 1- Few tendering documents contain language pertaining } \\
\text { measures in place? }\end{array}$ \\
& $\begin{array}{l}\text { to integrity violations; there is no specific policy, procedure, or } \\
\text { individual responsibilities and consequences with respect to public } \\
\text { procurement; evidence of enforcement is weak; no effectively } \\
\text { integrated anticorruption program. } \\
\text { 0- Tender documents generally do not cover integrity violations; } \\
\text { legal or regulatory framework does not deal with integrity } \\
\text { violations; there is no evidence of enforcement; the government } \\
\text { does not have an anticorruption program or codes relating to } \\
\text { conflict of interest. }\end{array}$ \\
\hline
\end{tabular}

Source: Asian Development Bank. 


\section{Appendix 5: Indicative Terms of Reference for a Country and Sector/Agency Procurement Risk Assessment}

\section{A. Background}

A5.1 [This section should include the background to the Country and Sector/ Agency Procurement Risk Assessment (CSPRA), either to support a new country partnership strategy (CPS), to provide inputs to the preparation of a results-based lending operation etc. In addition, the results of the initial country assessment should be included.]

\section{B. Purpose and Scope of the Assessment}

A5.2 Purpose: The CSPRA is intended to (i) identify risks in country and sector/agency systems and/or practices that could result in suboptimal use of national and/or Asian Development Bank (ADB) resources, either through leakage or inefficiency; (ii) assess the severity of the risks; and (iii) develop a practical risk management plan to address country and sector/agency procurement risks.

A5.3 Scope: The review team will

(i) Assess strengths and weaknesses in country procurement systems, including e-procurement systems, from the perspective of the legal and regulatory framework; the institutional framework and management capacity; procurement operations and market practices; and integrity and transparency of the public procurement systems, including the maturity of e-procurement systems in the country.

(ii) Assess strengths and weaknesses in sector/agency procurement systems and practices from the perspective of the legal and regulatory framework; the institutional framework and management capacity; procurement operations and market practices; and integrity and transparency of the public procurement systems.

(iii) Identify and evaluate procurement and market risks at the country and sector/agency level.

(iv) Propose prior and post review (sampling) approaches. 


\section{Approach and Methodology}

A5.4 The review will include, but is not limited to

(i) Validate or update the initial country assessment, primarily through consultation with government counterparts, development partners, and other relevant stakeholders using the country tool.

(ii) Assess sector/agency procurement performance, based on interviews with government counterparts, development partners, and relevant stakeholders supported by sampling of specific procurement transactions. The sector/agency tool should be completed for each of the key agencies within the sector, and the average score for the sector is then computed.

(iii) Prepare a narrative description of the country and sector/agency procurement systems, including identification of strengths and weaknesses.

(iv) Prepare a narrative description of the market and any risks that this presents to the envisioned procurement.

(v) Identify and assess procurement risks, based on risk likelihood and risk consequence.

(vi) Propose risk mitigation or management strategies to address identified risks.

(vii) Determine overall country, and where applicable, sector/agency procurement risk rating.

(viii) Summarize findings in the CSPRA report, including the maturity of e-procurement systems in the country.

(ix) [If applicable] Prepare inputs to the CPS, including the procurement risk assessment and management plan (P-RAMP).

\section{Key Deliverables}

(i) CSPRA report.

(ii) [If applicable] CPS inputs. 


\section{Appendix 6: Sector/Agency Procurement Assessment Tool}

A6.1 Table A6.1 describes the sector/agency procurement assessment tool. Table A6.2 describes the scoring guide for this tool. It is noted that this assessment tool is designed to assess practices under government financed procurement, not donor financed procurement. Accordingly it requires data collection and interviews with sector agencies and cannot be completed in the case of a rapid/update assessment based solely on ADB data sources.

Table A6.1: Sector/Agency Procurement Assessment Tool

\begin{tabular}{|c|c|c|c|}
\hline Indicators & Sector/Agency Questions & Score & $\begin{array}{c}\text { Narrative/ } \\
\text { Verification or } \\
\text { Clarification } \\
\text { Required }\end{array}$ \\
\hline \multicolumn{2}{|c|}{ 1. Legislative and Regulatory Framework } & $\begin{array}{l}\text { [Average } \\
\text { of } 1.1-1.5 \text { ] }\end{array}$ & \\
\hline $\begin{array}{l}\text { 1.1 Does the national } \\
\text { public procurement } \\
\text { law (including } \\
\text { supporting regulations, } \\
\text { standard bidding } \\
\text { documents and } \\
\text { operational manuals } \\
\text { or guides) apply to the } \\
\text { sector? }\end{array}$ & $\begin{array}{l}\text { - Is the sector exempted by legislation } \\
\text { from being subject to the national } \\
\text { public procurement law? } \\
\text { - Even if subject to the national public } \\
\text { procurement law, does the sector } \\
\text { tend to follow it? } \\
\text { - Do agencies in the sector use } \\
\text { government-issued public } \\
\text { procurement manuals or guidance? } \\
\text { - Have government-issued } \\
\text { documents been tailored to meet } \\
\text { sector requirements? } \\
\text { - In absence of government-issued } \\
\text { documents, does the sector have its } \\
\text { own standard bidding documents } \\
\text { or guidelines? }\end{array}$ & & $\begin{array}{l}\text { [The assessor } \\
\text { should give } \\
\text { a narrative } \\
\text { response and } \\
\text { determine } \\
\text { whether } \\
\text { additional } \\
\text { information or } \\
\text { verification is } \\
\text { required.] }\end{array}$ \\
\hline $\begin{array}{l}1.2 \text { Is the supply } \\
\text { market for the } \\
\text { sector sufficiently } \\
\text { competitive to give } \\
\text { full effect to the } \\
\text { national procurement } \\
\text { law and/or open } \\
\text { competitive } \\
\text { tendering? }\end{array}$ & $\begin{array}{l}\text { - Is competitive bidding a common } \\
\text { feature under the sector? } \\
\text { - Is there a core of suppliers in } \\
\text { the sector who regularly submit } \\
\text { responsive bids? } \\
\text { - What proportion, by percentage, } \\
\text { of the sector's procurement } \\
\text { is undertaken through open } \\
\text { competitive bidding? } \\
\text { - What is the average number of } \\
\text { bidders for publicly bid contracts? }\end{array}$ & & \\
\hline
\end{tabular}


Table A6.1 continued

\begin{tabular}{|c|c|c|c|}
\hline Indicators & Sector/Agency Questions & Score & $\begin{array}{c}\text { Narrative/ } \\
\text { Verification or } \\
\text { Clarification } \\
\text { Required }\end{array}$ \\
\hline & $\begin{array}{l}\text { - Do executing agencies tend to } \\
\text { make sufficient efforts to attract } \\
\text { bids (e.g., adequate advertising, } \\
\text { bidding periods)? } \\
\text { - Is there availability and quality of } \\
\text { suppliers, labor force, and/or related } \\
\text { goods and services in the domestic } \\
\text { market? }\end{array}$ & & \\
\hline $\begin{array}{l}1.3 \text { If there is a } \\
\text { sector-specific } \\
\text { legal framework, } \\
\text { does it support } \\
\text { nondiscriminatory } \\
\text { participation and } \\
\text { transparent tender } \\
\text { processes (including } \\
\text { advertisement, tender } \\
\text { documentation, } \\
\text { tender evaluation, } \\
\text { complaints } \\
\text { mechanism)? }\end{array}$ & $\begin{array}{l}\text { - Has the sector adopted } \\
\text { nondiscriminatory and transparent } \\
\text { tender processes? } \\
\text { - What is the average number of } \\
\text { bidders for publicly bid contracts? }\end{array}$ & & \\
\hline $\begin{array}{l}1.4 \text { Is the sector } \\
\text { subjected to } \\
\text { excessive regulation } \\
\text { or government } \\
\text { control such that } \\
\text { competition is limited } \\
\text { or nonexistent? }\end{array}$ & $\begin{array}{l}\text { - Does the sector apply a domestic } \\
\text { preference scheme? } \\
\text { - Does the sector require pre- } \\
\text { registration of bidders? } \\
\text { - Are there acceptable provisions in } \\
\text { the sector for the participation of } \\
\text { state-owned enterprises? }\end{array}$ & & \\
\hline $\begin{array}{l}1.5 \text { Does the legal and } \\
\text { regulatory framework } \\
\text { enable the sector/ } \\
\text { agency to use an } \\
\text { e-procurement } \\
\text { system? }\end{array}$ & $\begin{array}{l}\text { - Does the sector/agency abide by } \\
\text { the rules, regulations, and guidelines } \\
\text { for the use of e-procurement } \\
\text { incorporated in the national } \\
\text { procurement laws? } \\
\text { - Are electronic and paper } \\
\text { documents considered as equally } \\
\text { valid by the sector/agency? } \\
\text { - Are there sector/agency-specific } \\
\text { tender or bidding procedures, } \\
\text { contract management processes, } \\
\text { and approval ceilings in the } \\
\text { e-procurement implementation? }\end{array}$ & & \\
\hline
\end{tabular}


Table A6.1 continued

\begin{tabular}{|c|c|c|c|}
\hline Indicators & Sector/Agency Questions & Score & $\begin{array}{l}\text { Narrative/ } \\
\text { Verification or } \\
\text { Clarification } \\
\text { Required }\end{array}$ \\
\hline \multicolumn{2}{|c|}{ 2. Institutional Framework and Management Capacity } & $\begin{array}{l}\text { [Average } \\
\text { of } 2.1-2.6 \text { ] }\end{array}$ & \\
\hline $\begin{array}{l}2.1 \text { Is the procurement } \\
\text { cycle in the sector } \\
\text { required to be tied to } \\
\text { an annual budgeting } \\
\text { cycle (i.e., can a } \\
\text { procurement activity } \\
\text { commence only when } \\
\text { budget has been duly } \\
\text { appropriated for it)? }\end{array}$ & $\begin{array}{l}\text { - Are procurement plans in the sector } \\
\text { prepared as part of the budget } \\
\text { planning and formulation process? } \\
\text { - Do systems and processes in the } \\
\text { sector or key agencies in the sector } \\
\text { require certification of availability of } \\
\text { funds before solicitation of tenders? }\end{array}$ & & \\
\hline $\begin{array}{l}2.2 \text { Does the system } \\
\text { foster efficiency } \\
\text { through the use of } \\
\text { adequate planning? }\end{array}$ & $\begin{array}{l}\text { Does the sector, or key agencies } \\
\text { in the sector, have a formalized } \\
\text { procurement planning process }(\mathrm{s}) \text { ? }\end{array}$ & & \\
\hline $\begin{array}{l}2.3 \text { Does the } \\
\text { procurement system } \\
\text { in the sector feature } \\
\text { an oversight or } \\
\text { regulatory body? }\end{array}$ & $\begin{array}{l}\text { - Does the sector fall under the } \\
\text { remit of the national oversight or } \\
\text { regulatory body? } \\
\text { - If a national body does not exist, } \\
\text { is there a sector-specific body } \\
\text { that oversees and/or regulates } \\
\text { procurement? }\end{array}$ & & \\
\hline $\begin{array}{l}2.4 \text { Is there a public } \\
\text { procurement capacity } \\
\text { development or } \\
\text { professionalization } \\
\text { program? }\end{array}$ & $\begin{array}{l}\text { - What proportions of procurement- } \\
\text { related officers and staff in } \\
\text { - the sector have been trained } \\
\text { under the national or sector } \\
\text { capacity development program } \\
\text { or participated in any formal } \\
\text { procurement training program? }\end{array}$ & & \\
\hline $\begin{array}{l}2.5 \text { Is there a } \\
\text { dedicated group } \\
\text { institutionalized for } \\
\text { e-procurement in } \\
\text { the sector/agency's } \\
\text { procurement unit? }\end{array}$ & $\begin{array}{l}\text { - Does the sector/agency use the } \\
\text { national e-procurement system or } \\
\text { does it use its own e-procurement } \\
\text { system? } \\
\text { - Is e-procurement strategically } \\
\text { positioned in the sector/agency's } \\
\text { governance map or long-term } \\
\text { development plan? } \\
\text { - How is e-procurement positioned } \\
\text { within the overall sector/agency } \\
\text { structure? } \\
\text { - Does the sector/agency have } \\
\text { sufficient IT infrastructure to } \\
\text { support e-procurement? }\end{array}$ & & \\
\hline
\end{tabular}


Table A6.1 continued

\begin{tabular}{|c|c|c|c|}
\hline Indicators & Sector/Agency Questions & Score & $\begin{array}{l}\text { Narrative/ } \\
\text { Verification or } \\
\text { Clarification } \\
\text { Required }\end{array}$ \\
\hline $\begin{array}{l}2.6 \text { If an } \\
\text { e-procurement } \\
\text { system is used, is there } \\
\text { a structured approach } \\
\text { to capacity building } \\
\text { and analyzing its } \\
\text { effective use? }\end{array}$ & $\begin{array}{l}\text { - What is the sector/agency's } \\
\text { e-procurement capacity to } \\
\text { implement the system? } \\
\text { - Does the agency or e-procurement } \\
\text { unit recognize the need for } \\
\text { knowledge and skill building for } \\
\text { the new way of working under } \\
\text { e-procurement? }\end{array}$ & & \\
\hline \multicolumn{2}{|c|}{ 3. Procurement Operations and Market Practices } & $\begin{array}{l}\text { [Average } \\
\text { of 3.1-3.5] }\end{array}$ & \\
\hline $\begin{array}{l}3.1 \text { Is private sector } \\
\text { competitive, well } \\
\text { organized and able } \\
\text { to access the sector } \\
\text { market? }\end{array}$ & $\begin{array}{l}\text { - Is the private sector well organized } \\
\text { and able to access the sector } \\
\text { market? } \\
\text { - Do civil society organizations regard } \\
\text { public procurement in the sector } \\
\text { - to be open and accessible to the } \\
\text { market? }\end{array}$ & & \\
\hline $\begin{array}{l}\text { 3.2 Do measures } \\
\text { exist in the sector to } \\
\text { ensure the adequacy } \\
\text { and accuracy of cost } \\
\text { estimates before } \\
\text { bidding, and to } \\
\text { manage contract price } \\
\text { variations? }\end{array}$ & $\begin{array}{l}\text { - What percentage of contracts are } \\
\text { awarded for values less than the } \\
\text { original cost estimates? } \\
\text { - What percentage of contract } \\
\text { variations amount to a cumulative } \\
\text { impact of more than } 10 \% \text { of the } \\
\text { original contract price? }\end{array}$ & & \\
\hline $\begin{array}{l}3.3 \text { Is the private } \\
\text { sector able to access } \\
\text { and fully participate in } \\
\text { the agency } \\
\text { e-procurement } \\
\text { activities? }\end{array}$ & $\begin{array}{l}\text { - What functions exist and are } \\
\text { being used in the sector/agency } \\
\text { e-procurement system? } \\
\text { - Are all forms available and } \\
\text { accessible online? } \\
\text { - Do bidders pay any fees for the use } \\
\text { of the system? } \\
\text { - What other government IT systems } \\
\text { does the e-procurement system } \\
\text { link to? } \\
\text { - Are foreign bidders able to } \\
\text { participate in sector/agency's } \\
\text { e-procurement system? } \\
\text { - What percentage of sector/agency's } \\
\text { total bids are transacted through } \\
\text { the e-procurement system? }\end{array}$ & & \\
\hline
\end{tabular}


Table A6.1 continued

\begin{tabular}{|c|c|c|c|}
\hline Indicators & Sector/Agency Questions & Score & $\begin{array}{l}\text { Narrative/ } \\
\text { Verification or } \\
\text { Clarification } \\
\text { Required }\end{array}$ \\
\hline $\begin{array}{l}\text { 3.4 Do commercial } \\
\text { bank practices } \\
\text { support the private } \\
\text { sector industry } \\
\text { and procurement } \\
\text { operations } \\
\text { adequately? }\end{array}$ & $\begin{array}{l}\text { - Have banks delegated powers } \\
\text { to branches to issue bid security, } \\
\text { advance payment security, and } \\
\text { performance security expeditiously? } \\
\text { - Do banks generally play a } \\
\text { supporting role in assisting } \\
\text { contractors, especially small ones } \\
\text { for obtaining such securities? } \\
\text { - Do banks generally provide } \\
\text { necessary credit facilities to the } \\
\text { construction industry (especially } \\
\text { small- and medium-sized firms)? }\end{array}$ & & \\
\hline $\begin{array}{l}3.5 \text { Is there a } \\
\text { mechanism in the } \\
\text { sector to receive and } \\
\text { handle observations, } \\
\text { complaints, and } \\
\text { protests? }\end{array}$ & $\begin{array}{l}\text { - Are there sector-specific } \\
\text { procedures to receive and handle } \\
\text { observations, complaints, and } \\
\text { protests? } \\
\text { - Are complaints and protests in } \\
\text { the sector processed within the } \\
\text { maximum time limit provided for in } \\
\text { the law? } \\
\text { - Have bidders used the complaint } \\
\text { and protest mechanisms? }\end{array}$ & & \\
\hline \multicolumn{2}{|c|}{$\begin{array}{l}\text { 4. Integrity and Transparency of } \\
\text { the Sector Public Procurement System }\end{array}$} & $\begin{array}{c}\text { [Average } \\
\text { of } 4.1-4.4]\end{array}$ & \\
\hline $\begin{array}{l}4.1 \text { Is there a formal } \\
\text { internal control and } \\
\text { audit framework in the } \\
\text { sector? }\end{array}$ & $\begin{array}{l}\text { - Do key agencies in the sector have } \\
\text { an independent internal audit } \\
\text { function? } \\
\text { - Do key agencies in the sector } \\
\text { have adequate internal control } \\
\text { mechanisms to oversee the } \\
\text { procurement function? } \\
\text { - Are key agencies in the sector } \\
\text { subjected to regular performance } \\
\text { or value for money audits? } \\
\text { - Are key agencies in the sector } \\
\text { subjected to annual financial } \\
\text { audits? } \\
\text { - Are internal or external audit } \\
\text { findings and/or recommendations } \\
\text { acted on in a timely manner? }\end{array}$ & & \\
\hline
\end{tabular}


Table A6.1 continued

\begin{tabular}{|c|c|c|c|}
\hline Indicators & Sector/Agency Questions & Score & $\begin{array}{l}\text { Narrative/ } \\
\text { Verification or } \\
\text { Clarification } \\
\text { Required }\end{array}$ \\
\hline $\begin{array}{l}4.2 \text { Is information } \\
\text { pertaining to public } \\
\text { procurement in the } \\
\text { sector easy to find, } \\
\text { comprehensive, and } \\
\text { relevant? }\end{array}$ & $\begin{array}{l}\text {-What percentage of bids are } \\
\text { published in a medium that is easily } \\
\text { and freely accessible? } \\
\text { - Can bidders easily and freely access } \\
\text { bid information? } \\
\text { - What is the percentage of contract } \\
\text { awards announced in media that } \\
\text { are easily and freely accessible? } \\
\text { - Are third-party observers invited to } \\
\text { attend public biddings? }\end{array}$ & & \\
\hline $\begin{array}{l}4.3 \text { Can bidders and } \\
\text { other stakeholders } \\
\text { easily access sector/ } \\
\text { agency's procurement } \\
\text { information through } \\
\text { the e-procurement } \\
\text { system? }\end{array}$ & $\begin{array}{l}\text {-What is civil society's involvement } \\
\text { in the e-procurement system? } \\
\text { - What kind of dynamics exist } \\
\text { between or among private sector } \\
\text { and other stakeholder groups? } \\
\text { - Are bidders and other stakeholders } \\
\text { able to monitor all the sector/ } \\
\text { agency's e-procurement } \\
\text { transactions? }\end{array}$ & & \\
\hline $\begin{array}{l}\text { 4.4 Does the sector } \\
\text { have ethics and } \\
\text { anticorruption } \\
\text { measures in place? }\end{array}$ & $\begin{array}{l}\text { - Are there sector-specific } \\
\text { procedures to verify a bidder's } \\
\text { legitimate existence, track records, } \\
\text { financial capacity, and capacity to } \\
\text { complete the job? } \\
\text { - Are there sector-specific } \\
\text { procedures to rate performance } \\
\text { and/or debar bidders, suppliers, } \\
\text { contractors, and consultants for } \\
\text { ethical or integrity violations? } \\
\text { - Does the sector, or key agencies in } \\
\text { the sector, maintain a register of } \\
\text { - debarred suppliers, contractors, and } \\
\text { consultants? } \\
\text { - Are there sector-specific integrity } \\
\text { principles and guidelines? }\end{array}$ & & \\
\hline $\begin{array}{l}4.5 \text { Other risk } \\
\text { indicators from } \\
\text { external sources } \\
\text { or other ADB risk } \\
\text { indicators }\end{array}$ & $\begin{array}{l}\text { - Are there risk indicators from } \\
\text { external sources, e.g., Transparency } \\
\text { International, and/or ADB's own risk } \\
\text { indicators from (a) investigations } \\
\text { and violations (b) Proactive } \\
\text { Integrity Report findings? }\end{array}$ & & \\
\hline
\end{tabular}

e-procurement = electronic procurement, IT = information technology.

Source: Asian Development Bank. 


\section{Table A6.2: Sector/Agency Procurement Assessment Tool Scoring Guide}

Scoring Guide

\begin{tabular}{ll}
\hline Indicators & \multicolumn{1}{c}{ Sector/Agency Questions } \\
\hline 1. Legislative and Regulatory Framework \\
$\begin{array}{ll}\text { 1.1 Does the national } & \text { - Is the sector exempted } \\
\text { public procurement } & \text { by legislation from being } \\
\text { law (including } & \text { subject to the national public } \\
\text { supporting regulations, } & \text { procurement law? } \\
\text { standard bidding } & \text { - Even if subject to the national } \\
\text { documents and } & \text { public procurement law, does } \\
\text { operational manuals } & \text { the sector tend to follow it? } \\
\text { or guides) apply to the } & \text { - Do agencies in the sector use } \\
\text { sector? } & \text { government-issued public } \\
& \begin{array}{l}\text { procurement manuals or } \\
\text { guidance? }\end{array} \\
& \text { - Have government-issued } \\
& \text { documents been tailored to } \\
& \text { meet sector requirements? } \\
& \text { In absence of government- } \\
& \text { issued documents, does the } \\
& \text { sector have its own standard } \\
& \text { bidding documents and/or } \\
& \text { guidelines? }\end{array}$
\end{tabular}

3- The sector has its own regulations, processes, guidelines, and bidding documents that are superior to those in the national public procurement system.

2-The sector is subject to the national procurement law and tends to follow it. Generally, it uses the national procurement processes, guidelines, and bidding documents. 1-The sector is subject to the national procurement law but tends to not follow it. Frequent deviations from national procurement processes, guidelines, and bidding documents.

0 - The sector is exempt from, or does not follow, the national public procurement system, and does not have its own regulations, processes, guidelines, and bidding documents that compensate for this.

\begin{tabular}{|c|c|c|}
\hline $\begin{array}{l}1.2 \text { Is the supply market } \\
\text { for the sector } \\
\text { sufficiently competitive } \\
\text { to give full effect to the } \\
\text { national procurement } \\
\text { law and/or open } \\
\text { competitive tendering? }\end{array}$ & $\begin{array}{l}\text { - Is competitive bidding a } \\
\text { common feature under } \\
\text { the sector? } \\
\text { - Is there a core of suppliers } \\
\text { in the sector who regularly } \\
\text { submit responsive bids? } \\
\text { - What proportion, by } \\
\text { percentage, of the sector's } \\
\text { procurement is undertaken } \\
\text { through open competitive } \\
\text { bidding? } \\
\text { - What is the average number } \\
\text { of bidders for publicly bid } \\
\text { contracts? } \\
\text { - Do executing agencies tend } \\
\text { to make sufficient efforts to } \\
\text { attract bids (e.g., adequate } \\
\text { advertising, bidding periods)? } \\
\text { - Is there availability and quality } \\
\text { of suppliers, labor force, and/ } \\
\text { or related goods and services } \\
\text { in the domestic market? }\end{array}$ & $\begin{array}{l}\text { 3- Competitive bidding is more } \\
\text { prevalent (by percentage) in the } \\
\text { sector than generally evident in the } \\
\text { country. A core of suppliers in the } \\
\text { sector regularly submit responsive } \\
\text { bids. At least five bidders on average } \\
\text { per contract. Executing agencies } \\
\text { make sufficient efforts to attract bids. } \\
2 \text { - Competitive bidding in the } \\
\text { sector is consistent with that } \\
\text { generally evident in the country. } \\
\text { A core of suppliers in the sector } \\
\text { regularly submit bids, but are often } \\
\text { nonresponsive. At least three bidders } \\
\text { on average per contract. Executing } \\
\text { agencies generally make sufficient } \\
\text { efforts to attract bids. } \\
1 \text { - Competitive bidding in the sector } \\
\text { is less prevalent than that generally } \\
\text { evident in the country. Suppliers } \\
\text { tend to submit one-off, but often } \\
\text { responsive bids. At least two bidders } \\
\text { on average per contract. Executing } \\
\text { agencies often do not make sufficient } \\
\text { efforts to attract bids. }\end{array}$ \\
\hline
\end{tabular}


Table A6.2 continued

\begin{tabular}{|c|c|c|}
\hline Indicators & Sector/Agency Questions & Scoring Guide ${ }^{\mathrm{a}}$ \\
\hline & & $\begin{array}{l}0 \text { - Competitive bidding in the sector } \\
\text { is much weaker than that generally } \\
\text { seen in the country. Suppliers tend to } \\
\text { submit one-off, nonresponsive bids. } \\
\text { Less than two bidders on average per } \\
\text { contract. Executing agencies rarely } \\
\text { make sufficient efforts to attract bids. }\end{array}$ \\
\hline $\begin{array}{l}1.3 \text { If there is a } \\
\text { sector-specific } \\
\text { legal framework, } \\
\text { does it support } \\
\text { nondiscriminatory } \\
\text { participation and } \\
\text { transparent tender } \\
\text { processes (including } \\
\text { advertisement, tender } \\
\text { documentation, tender } \\
\text { evaluation, complaints } \\
\text { mechanism)? }\end{array}$ & $\begin{array}{l}\text { - Has the sector adopted } \\
\text { nondiscriminatory and } \\
\text { transparent tender processes? } \\
\text { - What is the average number } \\
\text { of bidders for publicly bid } \\
\text { contracts? }\end{array}$ & $\begin{array}{l}3 \text { - At least five bidders on average } \\
\text { per contract. } \\
2 \text { - At least three bidders on average } \\
\text { per contract. } \\
1 \text { - At least two bidders on average } \\
\text { per contract. } \\
0 \text { - Less than two bidders on average } \\
\text { per contract. }\end{array}$ \\
\hline $\begin{array}{l}1.4 \text { Is the sector } \\
\text { subjected to } \\
\text { excessive regulation } \\
\text { or government } \\
\text { control such that } \\
\text { competition is limited } \\
\text { or nonexistent? }\end{array}$ & $\begin{array}{l}\text { - Does the sector apply a } \\
\text { domestic preference scheme? } \\
\text { - Does the sector require } \\
\text { pre- registration of bidders? } \\
\text { - Are there acceptable } \\
\text { provisions in the sector for the } \\
\text { participation of state-owned } \\
\text { enterprises? }\end{array}$ & $\begin{array}{l}3 \text { - There are no restrictions on } \\
\text { nationality of bidders or origins } \\
\text { of goods. There is no domestic } \\
\text { preference scheme. Effective } \\
\text { preregistration processes are } \\
\text { rigorously followed. Acceptable } \\
\text { provisions govern participation of } \\
\text { state-owned enterprises. } \\
2 \text { - Norestrictions on nationality } \\
\text { of bidders or origin of goods, or } \\
\text { preregistration process exists but } \\
\text { is not rigorously followed, or weak } \\
\text { or unclear provisions governing } \\
\text { participation of state-owned } \\
\text { enterprises. } \\
1 \text { - Some restrictions on nationality } \\
\text { of bidders, or domestic preference } \\
\text { scheme exists, preregistration process } \\
\text { needs improvements, lack of clarity } \\
\text { on participation by state-owned } \\
\text { enterprises. } \\
0 \text { - Restrictions on nationality of } \\
\text { bidders, domestic preference scheme } \\
\text { in place, no preregistration of bidders } \\
\text { required, no specific guidance with } \\
\text { respect to state-owned enterprises. }\end{array}$ \\
\hline
\end{tabular}


Table A6.2 continued

\begin{tabular}{|c|c|c|}
\hline Indicators & Sector/Agency Questions & Scoring Guide ${ }^{a}$ \\
\hline $\begin{array}{l}1.5 \text { Does the legal and } \\
\text { regulatory framework } \\
\text { enable the sector/ } \\
\text { agency to use an } \\
\text { e-procurement } \\
\text { system? }\end{array}$ & $\begin{array}{l}\text { - Does the sector/agency abide } \\
\text { by the rules, regulations, } \\
\text { and guidelines for the use of } \\
\text { e-procurement incorporated } \\
\text { in the national procurement } \\
\text { laws? } \\
\text { - Are electronic and paper } \\
\text { documents considered as } \\
\text { equally valid by the sector/ } \\
\text { agency? } \\
\text { - Are there sector/agency- } \\
\text { specific tender and/or } \\
\text { bidding procedures, contract } \\
\text { management processes, } \\
\text { - and approval ceilings } \\
\text { in the e-procurement } \\
\text { implementation? }\end{array}$ & $\begin{array}{l}3 \text { - The sector/agency implements } \\
\text { the same e-procurement rules, } \\
\text { regulations, and guidelines consistent } \\
\text { with the national procurement laws. } \\
2 \text { - The sector/agency tender and/ } \\
\text { or bidding procedures and contract } \\
\text { management processes are subject to } \\
\text { the national e-procurement law, but } \\
\text { implement it with some variations } \\
\text { specific to sector/agency. } \\
1-\text { The sector/agency is subject to } \\
\text { the national e-procurement law, but } \\
\text { does not follow it. Sector/agency uses } \\
\text { its own rules and regulations. } \\
0 \text { - The sector/agency is exempt } \\
\text { from or does not follow the national } \\
\text { e-procurement system and does not } \\
\text { have its own regulation, processes, } \\
\text { and guidelines. }\end{array}$ \\
\hline
\end{tabular}

\section{Institutional Framework and Management Capacity}

2.1 Is the procurement cycle in the sector required to be tied to an annual budgeting cycle (i.e., can a procurement activity budget has been duly appropriated for it)? commence only when
- Are procurement plans in the sector prepared as part of the budget planning and formulation process?

- Do systems and processes in the sector or key agencies in the sector require certification of availability of funds before solicitation of tenders?
3 - Procurement plans are prepared as part of the annual budget process, and budget availability is confirmed prior to solicitation of tenders. 2 - Budget availability is confirmed prior to solicitation of tenders, but there is limited procurement planning serving as an input to budget formulation.

1 - Procurement planning factors into budget formulation, but budget availability need not be confirmed prior to solicitation of tenders. 0 - Procurement planning does not factor into budget formulation and budget availability need not be confirmed prior to solicitation of tenders.

$\begin{array}{ll}\text { 2.2 Does the system } & \text { - Does the sector, or key } \\ \text { foster efficiency } & \text { agencies in the sector, have } \\ \text { through the use of } & \text { a formalized procurement } \\ \text { adequate planning? } & \text { planning process(es)? }\end{array}$

3 - There is a regular planning exercise that starts with the preparation of multiyear operating plans followed by annual procurement plans with associated expenditures that form part of the annual budget formulation process. 
Table A6.2 continued

\begin{tabular}{|c|c|c|}
\hline Indicators & Sector/Agency Questions & Scoring Guide ${ }^{a}$ \\
\hline & & $\begin{array}{l}2 \text { - Multiyear operating plans and } \\
\text { annual procurement plans are } \\
\text { prepared independently of budget } \\
\text { preparation, but these are revised in } \\
\text { line with forward budget estimates. } \\
1 \text { - Annual procurement plans are } \\
\text { prepared, but these are not linked to } \\
\text { multiyear operating plans and/or not } \\
\text { linked to budget formulation. } \\
0 \text { - Procurement plans are not } \\
\text { prepared. }\end{array}$ \\
\hline $\begin{array}{l}2.3 \text { Does the } \\
\text { procurement system } \\
\text { in the sector feature } \\
\text { an oversight or } \\
\text { regulatory body? }\end{array}$ & $\begin{array}{l}\text { - Does the sector fall under the } \\
\text { remit of the national oversight } \\
\text { or regulatory body? } \\
\text { - If a national body does not } \\
\text { exist, is there a sector-specific } \\
\text { body that oversees and/or } \\
\text { regulates procurement? }\end{array}$ & $\begin{array}{l}3 \text { - There is a national procurement } \\
\text { oversight body that covers agency } \\
\text { procurement. } \\
2 \text { - There is no national body; } \\
\text { however, a sector-specific body } \\
\text { oversees and regulates procurement } \\
\text { in the sector. } \\
1 \text { - There is a national regulatory } \\
\text { body, but has limited clarity with } \\
\text { respect to its scope and/or ability to } \\
\text { oversee and/or regulate procurement } \\
\text { in the sector. } \\
0 \text { - There is no body, at the national } \\
\text { or sector level, that oversees or } \\
\text { regulates procurement. }\end{array}$ \\
\hline $\begin{array}{l}2.4 \text { Is there a public } \\
\text { procurement capacity } \\
\text { development or } \\
\text { professionalization } \\
\text { program? }\end{array}$ & $\begin{array}{l}\text { - What proportions of } \\
\text { procurement-related officers } \\
\text { and staff in the sector have } \\
\text { been trained under the } \\
\text { national or sector capacity } \\
\text { development program or } \\
\text { participated in any formal } \\
\text { procurement training program? }\end{array}$ & $\begin{array}{l}3 \text { - At least } 80 \% \text { of procurement staff. } \\
2 \text { - At least } 60 \% \text { of procurement staff. } \\
1 \text { - At least } 20 \% \text { of procurement staff. } \\
0 \text { - Less than } 20 \% \text { of procurement } \\
\text { staff. }\end{array}$ \\
\hline $\begin{array}{l}2.5 \text { Is there a dedicated } \\
\text { group institutionalized } \\
\text { for e-procurement in } \\
\text { the sector/agency's } \\
\text { procurement unit? }\end{array}$ & $\begin{array}{l}\text { - Does the sector/agency use } \\
\text { the national e-procurement } \\
\text { system or does it use its own } \\
\text { e-procurement system? } \\
\text { - Is e-procurement strategically } \\
\text { positioned in the sector/ } \\
\text { agency's governance map or } \\
\text { long-term development plan? }\end{array}$ & $\begin{array}{l}\text { 3-The sector/agency has its own } \\
\text { e-procurement unit, but there is } \\
\text { national oversight. E-procurement } \\
\text { is a strategy identified in the sector/ } \\
\text { agency's procurement plan. } \\
2 \text { - The sector/agency has its own } \\
\text { e-procurement unit but there is no } \\
\text { national oversight. Sector/agency- } \\
\text { specific body oversees e-procurement. }\end{array}$ \\
\hline
\end{tabular}


Table A6.2 continued

\begin{tabular}{|c|c|c|}
\hline Indicators & Sector/Agency Questions & Scoring Guide ${ }^{a}$ \\
\hline & $\begin{array}{l}\text { - How is e-procurement } \\
\text { positioned within the overall } \\
\text { sector/agency structure? } \\
\text { - Does the sector/agency have } \\
\text { sufficient IT infrastructure to } \\
\text { support e-procurement? }\end{array}$ & $\begin{array}{l}\text { 1-The sector/agency relies on the } \\
\text { national e-procurement unit and } \\
\text { there is limited clarity on the role and } \\
\text { responsibility for e-procurement in } \\
\text { the sector/agency. } \\
0 \text { - There is no dedicated group in } \\
\text { the sector/agency and no national } \\
e \text {-procurement unit. }\end{array}$ \\
\hline $\begin{array}{l}2.6 \text { If an e-procurement } \\
\text { system is used, is there } \\
\text { a structured approach } \\
\text { to capacity building } \\
\text { and analyzing its } \\
\text { effective use? }\end{array}$ & $\begin{array}{l}\text { - What is the sector/agency's } \\
\text { e-procurement capacity to } \\
\text { implement the system? } \\
\text { - Does the agency or } \\
\text { - e-procurement unit recognize } \\
\text { the need for knowledge and } \\
\text { skill building for the new way of } \\
\text { working under e-procurement? }\end{array}$ & $\begin{array}{l}\text { 3-At least } 75 \% \text { of e-procurement } \\
\text { staff have completed up to } 3 \text { weeks of } \\
\text { national e-procurement training. } \\
2 \text {-At least } 55 \% \text { of e-procurement } \\
\text { staff have completed a } 1 \text {-week } \\
\text { e-procurement training program. } \\
\text { 1-At least } 25 \% \text { of e-procurement } \\
\text { staff have completed a 1-day } \\
\text { e-procurement training program. } \\
\text { - - Up to 20\% of the e-procurement } \\
\text { staff have had no training. }\end{array}$ \\
\hline
\end{tabular}

\section{Procurement Operations and Market Practices}

3.1 Is the private sector $\quad$ Is the private sector well competitive, well organized and able to access the sector market? organized and able to access the sector market?

- Do civil society organizations regard public procurement in the sector to be open and accessible to the market?
3 - The private sector is competitive, well organized, and able to participate in the competition for sector procurement contracts. There are no major constraints inhibiting private access to sector procurement. 2 - There is a reasonably wellfunctioning private sector serving the sector/agency, but competition for large contracts is concentrated in a relatively small number of firms. There are some constraints inhibiting private sector access to sector procurement.

1-The private sector serving the sector/agency is relatively weak and/or competition is limited due to monopolistic or oligopolistic features. There are multiple constraints inhibiting private sector access to sector procurement.

0 - The private sector is not well organized and lacks capacity to access sector procurement markets. There are major constraints that discourage competition from the private sector. 
Table A6.2 continued

\begin{tabular}{|c|c|c|}
\hline Indicators & Sector/Agency Questions & Scoring Guide ${ }^{a}$ \\
\hline $\begin{array}{l}\text { 3.2 Do measures } \\
\text { exist in the sector to } \\
\text { ensure the adequacy } \\
\text { and accuracy of cost } \\
\text { estimates before } \\
\text { bidding, and to } \\
\text { manage contract price } \\
\text { variations? }\end{array}$ & $\begin{array}{l}\text { - What percentage of } \\
\text { contracts are awarded for } \\
\text { values less than the original } \\
\text { cost estimates? } \\
\text { - What percentage of contract } \\
\text { variations amount to a } \\
\text { cumulative impact of more } \\
\text { than } 10 \% \text { of the original } \\
\text { contract price? }\end{array}$ & $\begin{array}{l}\text { 3- More than } 75 \% \text { of the contract } \\
\text { awards sampled. } \\
2 \text { - 50\%-75\% of contract awards } \\
\text { sampled. } \\
1-20 \%-50 \% \text { of contract awards } \\
\text { sampled. } \\
0 \text { - Less than } 20 \% \text { of contract awards } \\
\text { sampled. } \\
3 \text { - Less than } 10 \% \text { of contracts } \\
\text { sampled. } \\
2-10 \%-20 \% \text { of contracts sampled. } \\
1-20 \%-50 \% \text { of contracts sampled. } \\
0-\text { More than } 50 \% \text { of contracts } \\
\text { sampled. }\end{array}$ \\
\hline $\begin{array}{l}3.3 \text { Is the private } \\
\text { sector able to access } \\
\text { and fully participate } \\
\text { in the sector/agency } \\
\text { e-procurement } \\
\text { activities? }\end{array}$ & $\begin{array}{l}\text { - What functions exist and } \\
\text { are being used in the } \\
\text { sector/ agency } \\
\text { e-procurement system? } \\
\text { - Are all forms available and } \\
\text { accessible online? } \\
\text { - Do bidders pay any fees for } \\
\text { the use of the system? } \\
\text { - What other government } \\
\text { IT systems does the } \\
\text { e-procurement system link to? } \\
\text { - Are foreign bidders able to } \\
\text { participate in sector/agency's } \\
\text { e-procurement system? } \\
\text { - What percentage of sector/ } \\
\text { agency's total bids are } \\
\text { transacted through the } \\
\text { e-procurement system? }\end{array}$ & $\begin{array}{l}3 \text { - Private sector is generally able to } \\
\text { access and participate competitively } \\
\text { through e-procurement; the } \\
\text { e-procurement system is an end-to- } \\
\text { end solution; there are no constraints } \\
\text { prohibiting any firm to access or use } \\
\text { the sector/agency e-procurement } \\
\text { system. } \\
2 \text { - E-procurement system is } \\
\text { accessible to the private sector, } \\
\text { but there are only a concentrated } \\
\text { number of firms in the sector that } \\
\text { are accessing and participating in } \\
\text { bidding. Use of the system is limited } \\
\text { to multilateral development bank- } \\
\text { funded projects. } \\
1-\text { The use ofe-procurement system } \\
\text { in the sector/agency is limited due to } \\
\text { noncompetitive factors. } \\
0 \text { - The private sector does not have } \\
\text { the capacity to access e-procurement } \\
\text { system; there are major system } \\
\text { constraints and weaknesses that } \\
\text { hinder the active participation in } \\
\text { e-procurement. }\end{array}$ \\
\hline $\begin{array}{l}\text { 3.4 Do commercial } \\
\text { bank practices } \\
\text { support the private } \\
\text { sector industry and } \\
\text { procurement } \\
\text { operations adequately? }\end{array}$ & $\begin{array}{l}\text { - Have banks delegated powers } \\
\text { to branches to issue bid } \\
\text { security, advance payment } \\
\text { security, and performance } \\
\text { security expeditiously? }\end{array}$ & $\begin{array}{l}\text { 3-Bank branches have adequate } \\
\text { powers to issue bid securities, } \\
\text { advance payment securities, and } \\
\text { performance securities without major } \\
\text { delays and reference to headquarters. } \\
\text { Private sector is generally able to } \\
\text { access bank credit facilities without } \\
\text { much hindrance. }\end{array}$ \\
\hline
\end{tabular}


Table A6.2 continued

\begin{tabular}{|c|c|c|}
\hline Indicators & Sector/Agency Questions & Scoring Guide ${ }^{a}$ \\
\hline & $\begin{array}{l}\text { - Do banks generally play a } \\
\text { supporting role in assisting } \\
\text { contractors, especially small } \\
\text { ones for obtaining such } \\
\text { securities? } \\
\text { - Do banks generally provide } \\
\text { necessary credit facilities to } \\
\text { the construction industry } \\
\text { (especially small and } \\
\text { medium-sized firms)? }\end{array}$ & $\begin{array}{l}2 \text { - Only some banks or branches } \\
\text { are generally geared to issue such } \\
\text { securities expeditiously and grant } \\
\text { credit facilities without much } \\
\text { hindrance to all competitive firms. } \\
1 \text { - Only some banks or branches } \\
\text { are generally geared to issue such } \\
\text { securities expeditiously and grant } \\
\text { credit facilities without much } \\
\text { hindrance, but they do so after } \\
\text { reference to headquarters and only to } \\
\text { large-and medium-sized firms. } \\
0 \text { - No bank can issue securities and } \\
\text { credit facilities without reference to } \\
\text { headquarters. Small firms cannot } \\
\text { obtain such facilities at all. }\end{array}$ \\
\hline $\begin{array}{l}3.5 \text { Is there a } \\
\text { mechanism in the } \\
\text { sector to receive and } \\
\text { handle observations, } \\
\text { complaints, and } \\
\text { protests? }\end{array}$ & $\begin{array}{l}\text { - Are there sector-specific } \\
\text { procedures to receive } \\
\text { and handle observations, } \\
\text { complaints, and protests? } \\
\text { - Are complaints and protests in } \\
\text { the sector processed within the } \\
\text { maximum time limit provided } \\
\text { for in the law? } \\
\text { - Have bidders used the } \\
\text { complaint and protest } \\
\text { mechanisms? }\end{array}$ & $\begin{array}{l}3 \text { - The complaint review system has } \\
\text { precise and reasonable conditions } \\
\text { and time frames for decision with } \\
\text { clear enforcement authority and } \\
\text { mechanisms; more than } 90 \% \text { of } \\
\text { complaints are processed with } \\
\text { stipulated time frames. } \\
2 \text { - There are terms and time frames } \\
\text { for resolution of complaints, but } \\
\text { authority for enforcement is unclear; } \\
\text { more than } 75 \% \text { of complaints } \\
\text { are processed within stipulated } \\
\text { time frames. } \\
1 \text { - Terms and time frames for } \\
\text { resolution of complaints are vague; } \\
\text { the time to resolve complaints is not } \\
\text { tracked by the agency. } \\
0 \text { - There is no effective or } \\
\text { functioning complaints mechanism. }\end{array}$ \\
\hline
\end{tabular}

\section{Integrity and Transparency of the Sector Public Procurement System}

\begin{tabular}{|c|c|c|}
\hline $\begin{array}{l}4.1 \text { Is there a formal } \\
\text { internal control and } \\
\text { audit framework in the } \\
\text { sector? }\end{array}$ & $\begin{array}{l}\text { Do key agencies in the sector } \\
\text { have an independent internal } \\
\text { audit function? } \\
\text { - Do key agencies in the sector } \\
\text { have adequate internal control } \\
\text { mechanisms to oversee the } \\
\text { procurement function? }\end{array}$ & $\begin{array}{l}3 \text { - The sector has an effective } \\
\text { internal control framework including } \\
\text { an independent internal audit } \\
\text { function; annual financial audits are } \\
\text { conducted; audit recommendations } \\
\text { are implemented within } 6 \text { months; } \\
\text { no significant outstanding audit } \\
\text { findings for more than } 6 \text { months. }\end{array}$ \\
\hline
\end{tabular}


Table A6.2 continued

\begin{tabular}{|c|c|c|}
\hline Indicators & Sector/Agency Questions & Scoring Guide ${ }^{a}$ \\
\hline & $\begin{array}{l}\text { - Are key agencies in the } \\
\text { sector subjected to regular } \\
\text { performance or value for } \\
\text { money audits? } \\
\text { - Are key agencies in the sector } \\
\text { subjected to annual financial } \\
\text { audits? } \\
\text { - Are internal or external } \\
\text { audit findings and/or } \\
\text { recommendations acted on } \\
\text { in a timely manner? }\end{array}$ & $\begin{array}{l}2 \text { - The sector has effective } \\
\text { segregation of duties; an internal } \\
\text { audit function exists, but capacity } \\
\text { is weak, or the function is not } \\
\text { sufficiently independent; annual } \\
\text { financial audits are audited with } \\
\text { reasonable time disposition of audit } \\
\text { findings. } \\
1 \text { - The sector has effective } \\
\text { segregation of duties and is subjected } \\
\text { to annual audit. There is no internal } \\
\text { audit function, and/or audit findings } \\
\text { are not disposed of in a timely } \\
\text { manner. } \\
0 \text { - The internal system is weak, with } \\
\text { no internal audit, limited external } \\
\text { audit and audit findings are not } \\
\text { disposed of in a timely manner. }\end{array}$ \\
\hline $\begin{array}{l}4.2 \text { Is information } \\
\text { pertaining to public } \\
\text { procurement in the } \\
\text { sector easy to find, } \\
\text { comprehensive, and } \\
\text { relevant? }\end{array}$ & $\begin{array}{l}\text {-What percentage of bids are } \\
\text { published in a medium that is } \\
\text { easily and freely accessible? } \\
\text { - Can bidders easily and freely } \\
\text { access bid information? } \\
\text { - What is the percentage of } \\
\text { contract awards announced } \\
\text { in media that are easily and } \\
\text { freely accessible? } \\
\text { - Are third-party observers } \\
\text { invited to attend public } \\
\text { biddings? }\end{array}$ & $\begin{array}{l}3 \text { - At least } 80 \% \text { of bids are published; } \\
\text { at least } 80 \% \text { of contract awards are } \\
\text { published; bidders can easily and } \\
\text { freely access bid and contract award } \\
\text { information; third-party observers } \\
\text { are invited to attend public biddings. } \\
2 \text { - At least } 60 \% \text { of bids are } \\
\text { published; at least } 60 \% \text { of contract } \\
\text { awards are published; bidders can } \\
\text { easily and freely access either bid } \\
\text { and/or contract award information; } \\
\text { third- party observers may attend } \\
\text { public biddings. } \\
1 \text { - At least } 20 \% \text { of bids are published; } \\
\text { at least } 20 \% \text { of contract awards } \\
\text { are published; bidders have some } \\
\text { access to bid and contract award } \\
\text { information. } \\
0 \text { - Less than } 20 \% \text { of bids are } \\
\text { published; less than } 20 \% \text { of contract } \\
\text { awards are published. }\end{array}$ \\
\hline $\begin{array}{l}4.3 \text { Can bidders and } \\
\text { other stakeholders } \\
\text { easily access sector/ } \\
\text { agency's procurement } \\
\text { information through } \\
\text { the e-procurement } \\
\text { system? }\end{array}$ & $\begin{array}{l}\text { - What is civil society's } \\
\text { involvement in the } \\
\text { e-procurement system? } \\
\text { - What kind of dynamics exist } \\
\text { between/among private sector } \\
\text { and other stakeholder groups? }\end{array}$ & $\begin{array}{l}\text { 3-At least } 80 \% \text { of bids and } \\
\text { awards information are published } \\
\text { and are readily accessible at all } \\
\text { times on an e-procurement site; } \\
\text { third-party observers from civil } \\
\text { society organizations and other } \\
\text { partner groups are able to access } \\
\text { and download e-procurement } \\
\text { information. Generally, very }\end{array}$ \\
\hline
\end{tabular}


Table A6.2 continued

\begin{tabular}{|c|c|c|}
\hline Indicators & Sector/Agency Questions & Scoring Guide ${ }^{a}$ \\
\hline & $\begin{array}{l}\text { - Are bidders and other } \\
\text { stakeholders able to } \\
\text { - monitor all the sector/agency's } \\
\text { e-procurement transactions? }\end{array}$ & $\begin{array}{l}\text { cooperative relationship from all } \\
\text { stakeholder groups; civil society } \\
\text { organizations and other partner } \\
\text { groups able use e-procurement } \\
\text { system for monitoring. } \\
2 \text { - At least } 55 \% \text { of bids and } \\
\text { awards information are published } \\
\text { and readily accessible at all times } \\
\text { on an e-procurement site; some } \\
\text { third-party observers from civil } \\
\text { society organizations and other } \\
\text { partner groups are able to access } \\
\text { and download e-procurement } \\
\text { information. Some stakeholder } \\
\text { groups are not supportive of } \\
\text { e-procurement. Some stakeholders } \\
\text { use e-procurement system to monitor } \\
\text { process and results. } \\
1 \text { - At least } 25 \% \text { of bids and awards } \\
\text { information are published and } \\
\text { readily accessible at all times on an } \\
\text { e-procurement site. Bidders } \\
\text { are able to access and download } \\
\text { e-procurement information. } \\
\text { Negligible stakeholder support for } \\
\text { e-procurement. } \\
0 \text { - Below } 20 \% \text { of bids and awards } \\
\text { information are published and } \\
\text { readily accessible at all } \\
\text { times on an e-procurement site. } \\
\text { Bidders are unable to access } \\
\text { and download e-procurement } \\
\text { information. }\end{array}$ \\
\hline $\begin{array}{l}\text { 4.4 Does the sector } \\
\text { have ethics and } \\
\text { anticorruption } \\
\text { measures in place? }\end{array}$ & $\begin{array}{l}\text { - Are there sector-specific } \\
\text { procedures to verify a bidder's } \\
\text { legitimate existence, track } \\
\text { records, financial capacity, and } \\
\text { capacity to complete the job? } \\
\text { - Are there sector-specific } \\
\text { procedures to rate } \\
\text { performance and/or debar } \\
\text { bidders, suppliers, contractors, } \\
\text { and consultants for ethical or } \\
\text { integrity violations? }\end{array}$ & $\begin{array}{l}\text { 3- The sector has an active } \\
\text { anticorruption or integrity } \\
\text { program(s) in place; the sector has } \\
\text { mechanisms to debar firms for failure } \\
\text { to perform and/or integrity violations; } \\
\text { the sector has sufficient supplier } \\
\text { due diligence processes; the sector } \\
\text { has clear policy, procedures, and/ } \\
\text { or frameworks governing conflict of } \\
\text { interest. }\end{array}$ \\
\hline
\end{tabular}


Table A6.2 continued

\begin{tabular}{|c|c|c|}
\hline Indicators & Sector/Agency Questions & Scoring Guide ${ }^{a}$ \\
\hline & $\begin{array}{l}\text { - Does the sector, or key } \\
\text { agencies in the sector, maintain } \\
\text { a register of debarred suppliers, } \\
\text { contractors, and consultants? } \\
\text { - Are there sector-specific } \\
\text { integrity principles and } \\
\text { guidelines? }\end{array}$ & $\begin{array}{l}2 \text { - The sector has mechanisms to } \\
\text { debar firms for failure to perform } \\
\text { and/or integrity violations, or } \\
\text { mechanisms to report suspected } \\
\text { violations to a national or sector } \\
\text { wide anticorruption body; the sector } \\
\text { has sufficient supplier due diligence } \\
\text { processes; the concept of conflict of } \\
\text { interest is defined. } \\
1 \text { - The sector has sufficient supplier } \\
\text { due diligence processes, including } \\
\text { need to address conflict of interest. } \\
0 \text { - The sector does not have a formal } \\
\text { system(s) to deal with integrity } \\
\text { violations, conflicts of interest, and/or } \\
\text { integrity violations. }\end{array}$ \\
\hline $\begin{array}{l}4.5 \text { Other risk } \\
\text { indicators from } \\
\text { external sources } \\
\text { or other ADB risk } \\
\text { indicators. }\end{array}$ & $\begin{array}{l}\text { - Are there risk indicators } \\
\text { from external sources, } \\
\text { e.g., Transparency } \\
\text { International, and/or ADB's } \\
\text { own risk indicators from } \\
\text { (a) investigations and } \\
\text { violations (b) Proactive } \\
\text { Integrity Report findings? }\end{array}$ & $\begin{array}{l}\text { 3- There are no risk indicators from } \\
\text { external sources or ADB's own risk } \\
\text { indicators. } \\
2 \text { - There are minimal risk indicators } \\
\text { from external sources and/or ADB's } \\
\text { own risk indicators. } \\
1 \text { - There are concerning risk } \\
\text { indicators from external sources } \\
\text { and/or ADB's own risk indicators. } \\
0-\text { There are significant risk } \\
\text { indicators from external sources } \\
\text { and/or ADB's own risk indicators. }\end{array}$ \\
\hline
\end{tabular}

e-procurement = electronic procurement, IT = information technology.

a This guide does not replace professional judgment about the capacity of the sector/agency relative to that of the country procurement system. If considerations other than this guide are used, mention them in the "Narrative" column of the tool.

Source: Asian Development Bank. 


\section{Appendix 7: Report Outline for a \\ Country and Sector/Agency Procurement Risk Assessment}

\section{A. Executive Summary}

A7.1 [This section should give the overall result of the country and sector/agency procurement risk assessment (CSPRA) (low, moderate, substantial, high); summarize weaknesses and risks identified; and summarize mitigation and/or management measures to be adopted.]

\section{B. Introduction}

A7.2 [This section should indicate that the assessment was prepared in accordance with the Guidance Note on Procurement Risk Framework of the Asian Development Bank (ADB) and should indicate whether the CSPRA is being prepared to support a country partnership strategy. In addition, the section should indicate when and how the assessment was undertaken, e.g., "The CSPRA was undertaken from [date] to [date]. Preparation activities included reviewing documents, assessing ADB's ongoing procurement experience, and undertaking interviews with counterparts and discussions with stakeholders.']

\section{Country Procurement Risk Assessment}

1. Overview

A7.3 [This section should give a narrative description of the country procurement systems covering

(i) legislative and regulatory framework,

(ii) institutional framework and management capacity,

(iii) procurement operations and market practices,

(iv) performance of e-procurement system(s) (or plans to introduce one), and

(v) integrity and transparency of the public procurement system (including the maturity of e-procurement system[s]).]

\section{Strengths}

A7.4 [This section should identify strengths of the country procurement system, including those elements such as e-procurement which ADB may wish to rely upon. 
This should be based on the results of the country procurement assessment tool (Appendix 4), identifying those areas with scores of 2 or 3.]

\section{Weaknesses}

A7.5 [This section should identify weaknesses of the country procurement system. This should be based on the results of the country procurement assessment tool (Appendix 4), identifying those areas with scores of 0 or 1.]

\section{Procurement Risk Assessment and Management Plan}

A7.6 [Based on the weaknesses identified, ADB's fiduciary risks should be identified and assessed based on their likelihood of occurrence and degree of impact, and mitigation or management measures should be identified.]

\section{Sector/Agency Procurement Assessment(s)}

A7.7 [For each sector/agency assessed, the following topics should be covered.]

\section{Overview}

A7.8 [This section should make clear whether the assessment is based solely on practices on $A D B$ financed procurement, or on practices on both government and donor financed procurement. It should give a narrative description of the sector/agency procurement practices covering

(i) legislative and regulatory framework (from the sector perspective, this should reflect the compliance and/or implementation of sector agencies with national or country systems and frameworks);

(ii) institutional framework and management capacity;

(iii) procurement operations and market practices (from the sector perspective, the review of the market is particularly important, the assessment should consider whether domestic systems support international competitive bidding, the number of foreign bidders in domestic procurement, the percentage of internationally bid procurements won by local bidders, etc.this may be a summary of the sector issues raised in the market analysis where appropriate);

(iv) performance of e-procurement system(s) (or plans to introduce one); and

(v) integrity and transparency of the public procurement system (including the maturity of e-procurement system [s]).]

\section{Strengths}

A7.9 [This section should identify strengths of the sector/agency procurement practices, including those elements such as e-procurement which ADB may wish to rely upon. This should be based on the results of the sector/agency procurement assessment tool (Appendix 6), identifying those areas with scores of 2 or 3.] 


\section{Weaknesses}

A7.10 [This section should identify weaknesses of the sector/agency procurement practices. This should be based on the results of the sector/agency procurement assessment tool (Appendix 6), identifying those areas with scores of 0 or 1.]

\section{Procurement Risk Assessment and Management Plan}

A7.11 [Based on the weaknesses identified, ADB's fiduciary risks should be identified and assessed based on their likelihood of occurrence and degree of impact, and mitigation and/or management measures should be identified.]

\section{E. Market Risk Assessment(s)}

A7.12 [For each sector/agency assessed, the following topics should be covered.]

\section{Overview}

A7.13 [To the extent possible at the stage of the CSPRA, this section should give a narrative description of the relevant product or service market and of any cross-cutting market risks, including

(i) degree of concentration of firms in the market, balance between national and international firms, indicative contract values for which sufficient national firms can participate to permit competition, and minimum contract sizes that interest foreign bidders;

(ii) existence of otherwise of unhealthy patterns such as market dominance by one or a small number of firms, collusive behaviour, inability for either foreign or national firms to participate, impact of state owned (or former state owned) enterprises, abnormally low bidding, lack of interest or inability of reputable firms to win bids, use of inappropriate qualification criteria or bidding methods, inability of small and medium enterprises to participate, and other patterns inconsistent with sustainable development of capacity in the supply chain; and

(iii) application of domestic preferences; restrictions on foreign bidders; licensing, registration, etc.]

\section{Strengths}

A7.14 [This section should identify strengths of the market, including those which indicate the most appropriate level of competition and contract packaging.]

\section{Weaknesses}

A7.15 [This section should identify weaknesses of the market, identifying those areas which might jeopardize success of the project.] 


\section{Recommendations to Mitigate Risks}

A7.16 [Based on the weaknesses identified, fiduciary risks should be identified, assessed based on likelihood of occurrence and degree of impact, and mitigation and/or management measures identified.]

\section{F. Country (and, Where Applicable, Sector/Agency) Prior and Post Review (Sampling) Approach}

A7.17 [The review should recommend overall procurement risk rating at the country, and, where applicable, sector/agency level; and inform of the procurement review approach.]

\section{G. Conclusion}

A7.18 [State (a) the country and priority sector/agency risk ratings and rationale for the ratings, (b) reasons for change from the previous CSPRA country and sector risk ratings, and (c) key risks identified and recommended mitigation or management measures to address these risks in ADB operations. If use of country systems is under consideration in the country for results based lending, highlight any key gaps with ADB policy. State preferred procurement methods (e.g. open competitive bidding) and level of advertising (e.g. local newspaper of national circulation and/or national public procurement portal if available).]

\section{H. Appendixes}

A7.19 [Completed questionnaires, scoring tools, terms of reference, etc.] 


\section{Appendix 8: Potential Risks from a Country and Sector/Agency Procurement Risk Assessment}

\begin{tabular}{|c|c|c|c|}
\hline Risk & Impact & Causes & Possible Mitigating Measures \\
\hline \multirow[t]{2}{*}{$\begin{array}{l}\text { Noncompetitive } \\
\text { bidding processes }\end{array}$} & \multirow[t]{2}{*}{$\begin{array}{l}\text { - Genuine } \\
\text { bidders do not } \\
\text { participate } \\
\text { - Procurement } \\
\text { delays } \\
\text { - Increased prices } \\
\text { - Reduced quality } \\
\text { - Reduced life } \\
\text { span of assets }\end{array}$} & $\begin{array}{l}\text { Political and/or other } \\
\text { interference in } \\
\text { procurement processes }\end{array}$ & $\begin{array}{l}\text { - Increased procurement } \\
\text { oversight (additional } \\
\text { prior review) } \\
\text { - Systematically outsource } \\
\text { procurement processes } \\
\text { to independent } \\
\text { procurement agents } \\
\text { - Introduce or strengthen } \\
\text { e-procurement }\end{array}$ \\
\hline & & Barriers to entry & $\begin{array}{l}\text { - Ensure widest possible } \\
\text { competition by } \\
\text { international advertising } \\
\text { - Ensure inappropriate } \\
\text { packaging or qualification } \\
\text { criteria are not used } \\
\text { - Impose safeguards into } \\
\text { applicable procurement } \\
\text { system to remedy deficiencies } \\
\text { - Work with government to } \\
\text { reduce "red tape" for foreign } \\
\text { companies to operate in } \\
\text { the country }\end{array}$ \\
\hline $\begin{array}{l}\text { National } \\
\text { procurement } \\
\text { system does } \\
\text { not meet } \\
\text { international } \\
\text { standards }\end{array}$ & $\begin{array}{l}\text { Procurement } \\
\text { processes are } \\
\text { - inefficient, } \\
\text { - ineffective, } \\
\text { - nontransparent, } \\
\text { and/or } \\
\text { - unfair } \\
\text { with } \\
\text { - increased prices, } \\
\text { - reduced quality, } \\
\text { - procurement } \\
\text { delays, and/or } \\
\text { - loss of funding } \\
\text { allocation. }\end{array}$ & $\begin{array}{l}\text { Weaknesses in domestic } \\
\text { procurement legal or } \\
\text { regulatory framework }\end{array}$ & $\begin{array}{l}\text { - Ensure application of ADB } \\
\text { procurement regulations and } \\
\text { standard bidding documents, } \\
\text { or alternative procurement } \\
\text { arrangements by other } \\
\text { multilateral development } \\
\text { banks, as appropriate } \\
\text { - If open competitive bidding } \\
\text { is permitted under national } \\
\text { system, safeguards to be put in } \\
\text { place to remedy deficiencies } \\
\text { - Targeted capacity } \\
\text { development } \\
\text { - Recommend assistance to } \\
\text { government to improve the } \\
\text { legal or regulatory framework } \\
\text { (under the country } \\
\text { partnership strategy or a } \\
\text { specific project) }\end{array}$ \\
\hline
\end{tabular}


Appendix 8 continued

\begin{tabular}{|c|c|c|c|}
\hline Risk & Impact & Causes & Possible Mitigating Measures \\
\hline $\begin{array}{l}\text { Poor } \\
\text { procurement } \\
\text { planning } \\
\text { (packaging, } \\
\text { technical } \\
\text { specifications, } \\
\text { contracting } \\
\text { strategy) and } \\
\text { processing }\end{array}$ & $\begin{array}{l}\text { - Increased prices } \\
\text { - Purchase of } \\
\text { unsuitable } \\
\text { products or } \\
\text { services } \\
\text { - Procurement } \\
\text { delays } \\
\text { - Loss of funding } \\
\text { allocation } \\
\text { - Reduced quality } \\
\text { - Reduced life } \\
\text { span of assets }\end{array}$ & Lack of capacity & $\begin{array}{l}\text { - Ensure market analysis } \\
\text { is undertaken to inform } \\
\text { procurement planning } \\
\text { - Additional use of consultants } \\
\text { in project and contract } \\
\text { preparation } \\
\text { - Capacity development } \\
\text { measures included in projects } \\
\text { - Recommend assistance } \\
\text { to government to develop } \\
\text { national procurement training } \\
\text { system and to work with } \\
\text { professional bodies and } \\
\text { universities to strengthen } \\
\text { syllabus }\end{array}$ \\
\hline \multirow[t]{2}{*}{$\begin{array}{l}\text { Deficient } \\
\text { contract } \\
\text { management }\end{array}$} & \multirow[t]{2}{*}{$\begin{array}{l}\text { - Contract failures } \\
\text { - Increased price } \\
\text { - Reduced quality } \\
\text { - Inefficiency, } \\
\text { wastage }\end{array}$} & Lack of capacity & $\begin{array}{l}\text { - Ensure appropriate contract } \\
\text { management provisions are } \\
\text { included in the standard } \\
\text { bidding documents used } \\
\text { - Work with executing agencies } \\
\text { to provide nominated } \\
\text { contract managers } \\
\text { with defined duties and } \\
\text { responsibilities } \\
\text { - Capacity development } \\
\text { measures included in projects }\end{array}$ \\
\hline & & $\begin{array}{l}\text { Corrupt practices } \\
\text { (collusion, bribe-seeking) }\end{array}$ & $\begin{array}{l}\text { - Ensure that applicable } \\
\text { procurement system reflects } \\
\text { provisions on corrupt } \\
\text { practices and related issues } \\
\text { consistent with ADB policy } \\
\text { - Strengthen oversight by } \\
\text { contract supervision by a } \\
\text { third-party consultant having } \\
\text { requisite delegated authority } \\
\text { - Capacity development } \\
\text { measures included in projects } \\
\text { focused on strengthening } \\
\text { transparency in processes and } \\
\text { increase awareness on ADB's } \\
\text { Anticorruption Policy } \\
\text { - Periodic review of } \\
\text { procurement review } \\
\text { arrangements } \\
\text { Consider civil society } \\
\text { participation in monitoring } \\
\text { procurement outputs }\end{array}$ \\
\hline
\end{tabular}


Appendix 8 continued

\begin{tabular}{|c|c|c|c|}
\hline Risk & Impact & Causes & Possible Mitigating Measures \\
\hline $\begin{array}{l}\text { Market, } \\
\text { regulatory } \\
\text { dominance of } \\
\text { country/ } \\
\text { sector procuring } \\
\text { agencies }\end{array}$ & $\begin{array}{l}\text { - Collusion } \\
\text { - Bribe-seeking } \\
\text { - Reduced } \\
\text { competition } \\
\text { - Increased price } \\
\text { - Reduced } \\
\text { transparency }\end{array}$ & Industry structure & $\begin{array}{l}\text { - Carefully consider } \\
\text { appropriate procurement } \\
\text { methods and procurement } \\
\text { packaging during } \\
\text { procurement planning to } \\
\text { enhance competition } \\
\text { - Consider imposing prior } \\
\text { approval for procurement } \\
\text { methods other than open } \\
\text { competitive bidding } \\
\text { - Capacity development } \\
\text { measures included in projects } \\
\text { focused on strengthening } \\
\text { transparency in processes and } \\
\text { increase awareness on ADB's } \\
\text { Anticorruption Policy } \\
\text { - Periodic review of } \\
\text { procurement review } \\
\text { arrangements } \\
\text { - Consider civil society } \\
\text { participation in monitoring } \\
\text { procurement activities }\end{array}$ \\
\hline $\begin{array}{l}\text { Limited oversight } \\
\text { of procurement } \\
\text { and expenditure } \\
\text { practices }\end{array}$ & $\begin{array}{l}\text { - Inefficiency } \\
\text { - Fraudulent } \\
\text { behavior } \\
\text { - Collusion }\end{array}$ & $\begin{array}{l}\text { Weak internal and/or } \\
\text { external audit }\end{array}$ & $\begin{array}{l}\text { - Increased oversight of } \\
\text { procurement by ADB by } \\
\text { prior review } \\
\text { - Capacity development } \\
\text { measures included in projects } \\
\text { focused on strengthening } \\
\text { transparency in processes and } \\
\text { increase awareness on ADB's } \\
\text { Anticorruption Policy }\end{array}$ \\
\hline $\begin{array}{l}\text { Collusion and/ } \\
\text { or other integrity } \\
\text { violations (e.g. } \\
\text { fraud, corruption, } \\
\text { coercion, conflict } \\
\text { of interest) are } \\
\text { undetected }\end{array}$ & $\begin{array}{l}\text { - Reputational } \\
\text { risk to ADB } \\
\text { - Genuine } \\
\text { bidders do not } \\
\text { participate } \\
\text { - Reduced } \\
\text { competition } \\
\text { - Increased prices } \\
\text { - Reduced quality }\end{array}$ & $\begin{array}{l}\text { No or ineffective } \\
\text { complaint handling } \\
\text { mechanism }\end{array}$ & $\begin{array}{l}\text { - Increased oversight of } \\
\text { procurement by ADB by } \\
\text { prior review or increased } \\
\text { external audit } \\
\text { - Undertake pattern analysis to } \\
\text { identify unhealthy patterns } \\
\text { in bid participation and } \\
\text { contract award } \\
\text { - Capacity development } \\
\text { measures included in projects } \\
\text { focused on strengthening } \\
\text { transparency in processes } \\
\text { and awareness of ADB's } \\
\text { anticorruption policy } \\
\text { - Periodic review of } \\
\text { procurement review } \\
\text { arrangements }\end{array}$ \\
\hline
\end{tabular}


Appendix 8 continued

\begin{tabular}{|c|c|c|c|}
\hline Risk & Impact & Causes & Possible Mitigating Measures \\
\hline & & & $\begin{array}{l}\text { - Work with government } \\
\text { to introduce or improve } \\
\text { complaint handling } \\
\text { mechanism in procurement } \\
\text { legislation or regulations } \\
\text { - Work with government to } \\
\text { introduce or strengthen } \\
\text { anticorruption authorities }\end{array}$ \\
\hline & & $\begin{array}{l}\text { Weak internal and/or } \\
\text { external audit }\end{array}$ & $\begin{array}{l}\text { - ADB's increased oversight of } \\
\text { procurement by prior review, } \\
\text { or increased external audit } \\
\text { - Capacity development } \\
\text { included in projects focused } \\
\text { on strengthening audit } \\
\text { functions }\end{array}$ \\
\hline
\end{tabular}

$\mathrm{ADB}=$ Asian Development Bank.

Source: Asian Development Bank. 


\section{Appendix 9: Procurement Risk Assessment and Management Plan Template}

\begin{tabular}{lll}
\hline Risk Description & \multicolumn{1}{c}{ Risk Assessment } & \multicolumn{1}{c}{$\begin{array}{c}\text { Mitigation Measures } \\
\text { or Risk Management Plan }\end{array}$} \\
\hline [Risk] & $\begin{array}{l}\text { Rate as Low, Moderate, } \\
\text { Substantial, High] }\end{array}$ & $\begin{array}{l}\text { [For risks that can be mitigated by the } \\
\text { executing agency, implementing agencies, } \\
\text { and ADB, specify major actions planned } \\
\text { (avoid, reduce, transfer, or accept) for } \\
\text { mitigation, responsible agencies, and } \\
\text { timelines for implementation. } \\
\text { These may reflect risks and responses } \\
\text { indicated in Appendix 8 or be designed to } \\
\text { achieve fitness for purpose. } \\
\text { For risks that are mitigated by other } \\
\text { agencies (e.g., government and other } \\
\text { development agencies), outline the key } \\
\text { mitigating measures.] }\end{array}$ \\
& & \\
\hline Overall & [Specify the overall risk rating] & \\
\hline
\end{tabular}

$\mathrm{ADB}=$ Asian Development Bank.

Source: Asian Development Bank. 


\section{Appendix 10: Concept Stage Procurement Risk Rating Tool}

\begin{tabular}{|c|c|c|}
\hline Ref & Component & Response \\
\hline 1. & $\begin{array}{l}\text { How many implementing agencies are proposed to be involved in } \\
\text { the project? }{ }^{a}\end{array}$ & $\{$ number\} \\
\hline 2. & $\begin{array}{l}\text { Do the proposed implementing agencies have procurement } \\
\text { experience under prior projects financed by ADB, MDBs, and/or } \\
\text { other development partners? }\end{array}$ & $\begin{array}{l}\square \text { ADB } \\
\square \text { Other MDB } \\
\square \text { No }\end{array}$ \\
\hline 3. & $\begin{array}{l}\text { Have the proposed implementing agencies experienced significant } \\
\text { procurement and/or contractual issues, including long procurement } \\
\text { lead times (bid invitation to contract signing) on past ADB or other } \\
\text { externally financed projects? }\end{array}$ & $\begin{array}{l}\square \text { Yes } \square \text { No } \\
\square \text { Not applicable }\end{array}$ \\
\hline 4. & $\begin{array}{l}\text { Did the proposed implementing agencies require external support on } \\
\text { past ADB-financed projects to process procurement transactions? }\end{array}$ & $\begin{array}{l}\square \text { Yes } \square \text { No } \\
\square \text { Not applicable }\end{array}$ \\
\hline 5. & Is advance contracting and/or retroactive financing expected? & $\begin{array}{l}\text { Advance } \\
\text { Contracting: } \\
\square \text { Yes } \square \text { No } \\
\text { Retroactive } \\
\text { Financing: } \\
\square \text { Yes } \square \text { No }\end{array}$ \\
\hline 6. & Are complex contracts expected?c & $\square$ Yes $\square$ No \\
\hline 7. & Are high value contracts ( $>\$ 50$ million) expected? & $\square$ Yes $\square$ No \\
\hline 8. & $\begin{array}{l}\text { Is the distribution of contracts under the project geographically } \\
\text { dispersed, which could add complexity in packaging, } \\
\text { implementation, and contract management? }\end{array}$ & $\square$ Yes $\square$ No \\
\hline 9. & $\begin{array}{l}\text { Are there any supply market restrictions expected in the provision } \\
\text { of the required goods, works, and nonconsulting and consulting } \\
\text { services?d }\end{array}$ & $\square$ Yes $\square$ No \\
\hline 10. & $\begin{array}{l}\text { Does the implementing agency have formal procedures }{ }^{\mathrm{e}} \text { in place for } \\
\text { contract management? }\end{array}$ & $\square$ Yes $\square$ No \\
\hline 11. & Will an e-procurement system be used on the project? & $\square$ Yes $\square$ No \\
\hline \multicolumn{3}{|c|}{ Narrative details and regional department's overall comments (\{insert staff name\}) } \\
\hline \multicolumn{3}{|c|}{$\begin{array}{l}\text { Include further details related to the responses provided here as well as a narrative summary } \\
\text { detailing what, in the opinion of the project officer, are the main procurement risks that have the } \\
\text { potential to impact project success and any proposed risk mitigation measures that are being } \\
\text { considered. If external procurement support (e.g., consultants) is likely to be required, please } \\
\text { also provide details. }\end{array}$} \\
\hline
\end{tabular}


Appendix 10 continued

\section{PPFD comments and concept stage procurement risk rating (\{insert staff name\})}

The PPFD procurement specialist will validate the information provided by the regional department and supplement with additional information, where relevant. When available, the country and sector/agency procurement risk assessment will be consulted.

The project procurement risk, pre-mitigation, is assessed to be \{low\} \{moderate\} \{substantial\} \{high\}

$\mathrm{ADB}=$ Asian Development Bank; $\mathrm{MDB}=$ multilateral development bank; PPFD = Procurement, Portfolio and Financial Management Department.

a In instances where the executing agency is also the implementing agency, the assessment will be conducted on the executing agency.

b Identify in the accompanying narrative if experience with ADB was under the ADB Procurement Policy (2017, as amended from time to time) or Procurement Guidelines (2015, as amended from time to time); and whether the type of procurement undertaken was similar. If the response is "other MDB," provide project details if information exists.

c The complexity will be compared with recent externally financed projects managed by the implementing agency and includes innovative contract formats (public-private partnership, design and build, operation and maintenance, etc.) where the implementing agency has no prior experience in their use.

d Can include instances where there may be a limited domestic supply market; the packages to be procured will not generate international interest; supply of input elements (e.g., raw materials) is restricted; or there are limited providers for the goods, works, or services required.

e Is the area of contract management detailed under the applicable procurement or related legal framework? Are there operational procedures that guide staff on how to undertake contract management activities?

f If the response is Yes, provide the web address (e.g. http://.....) for the system in the accompanying narrative.

Source: Asian Development Bank. 


\section{Appendix 11: Sector Market Analysis Examples}

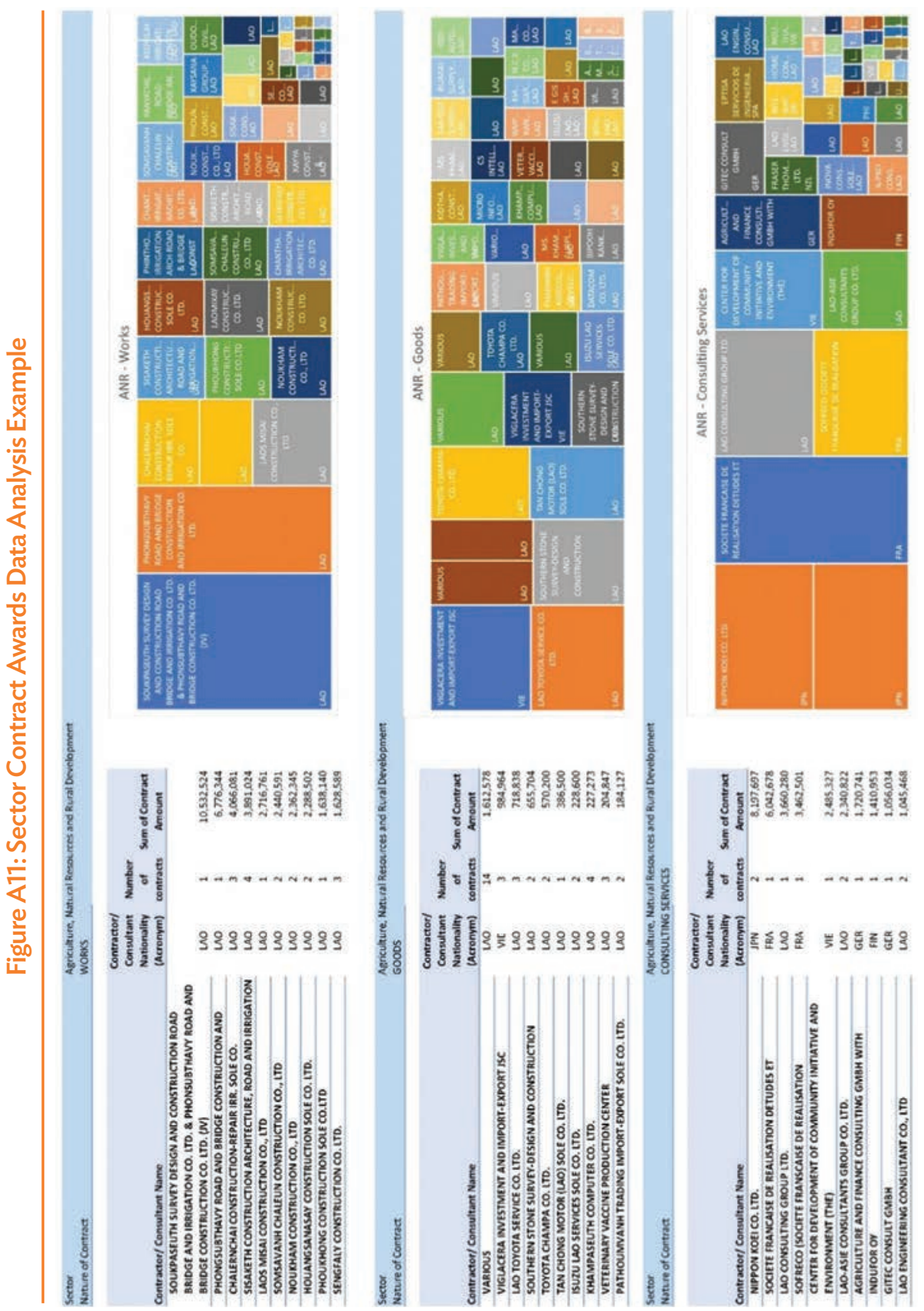




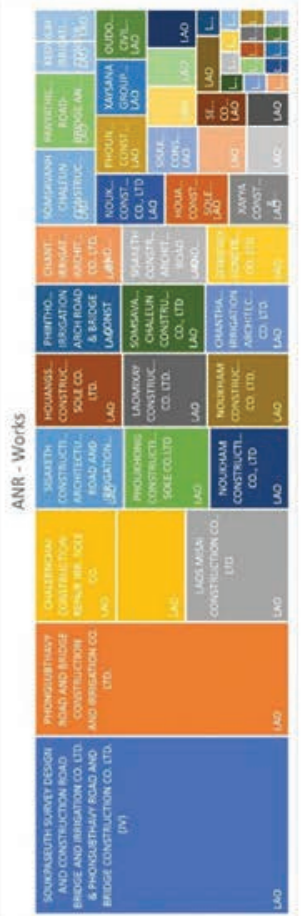

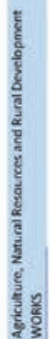

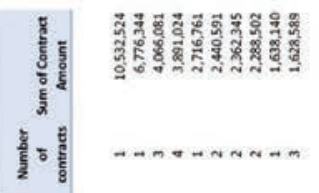

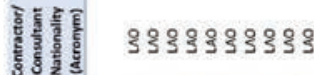

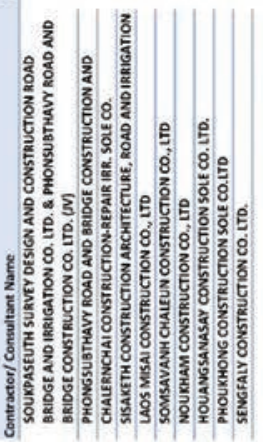

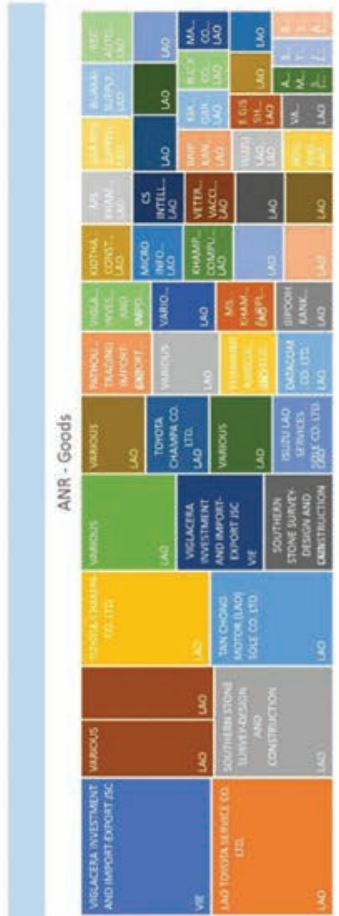

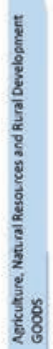
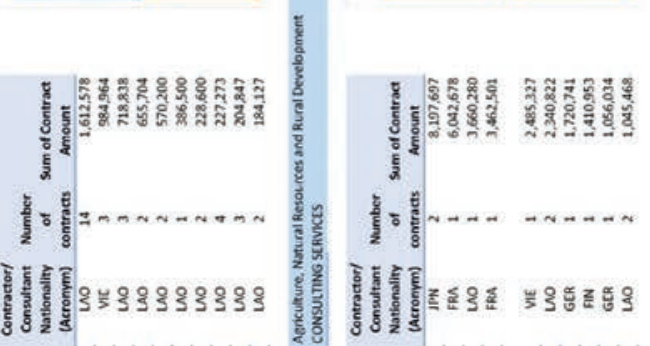

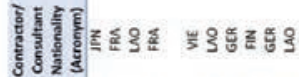
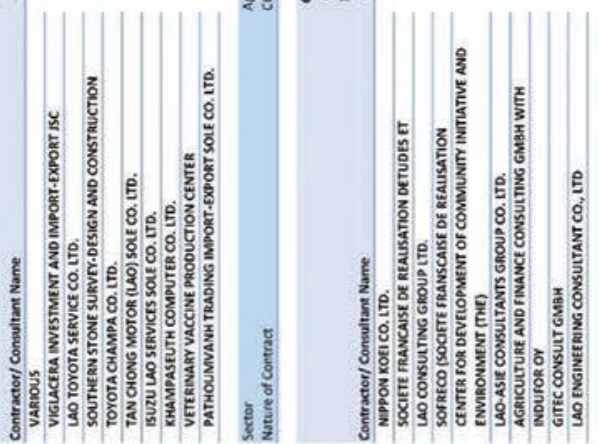


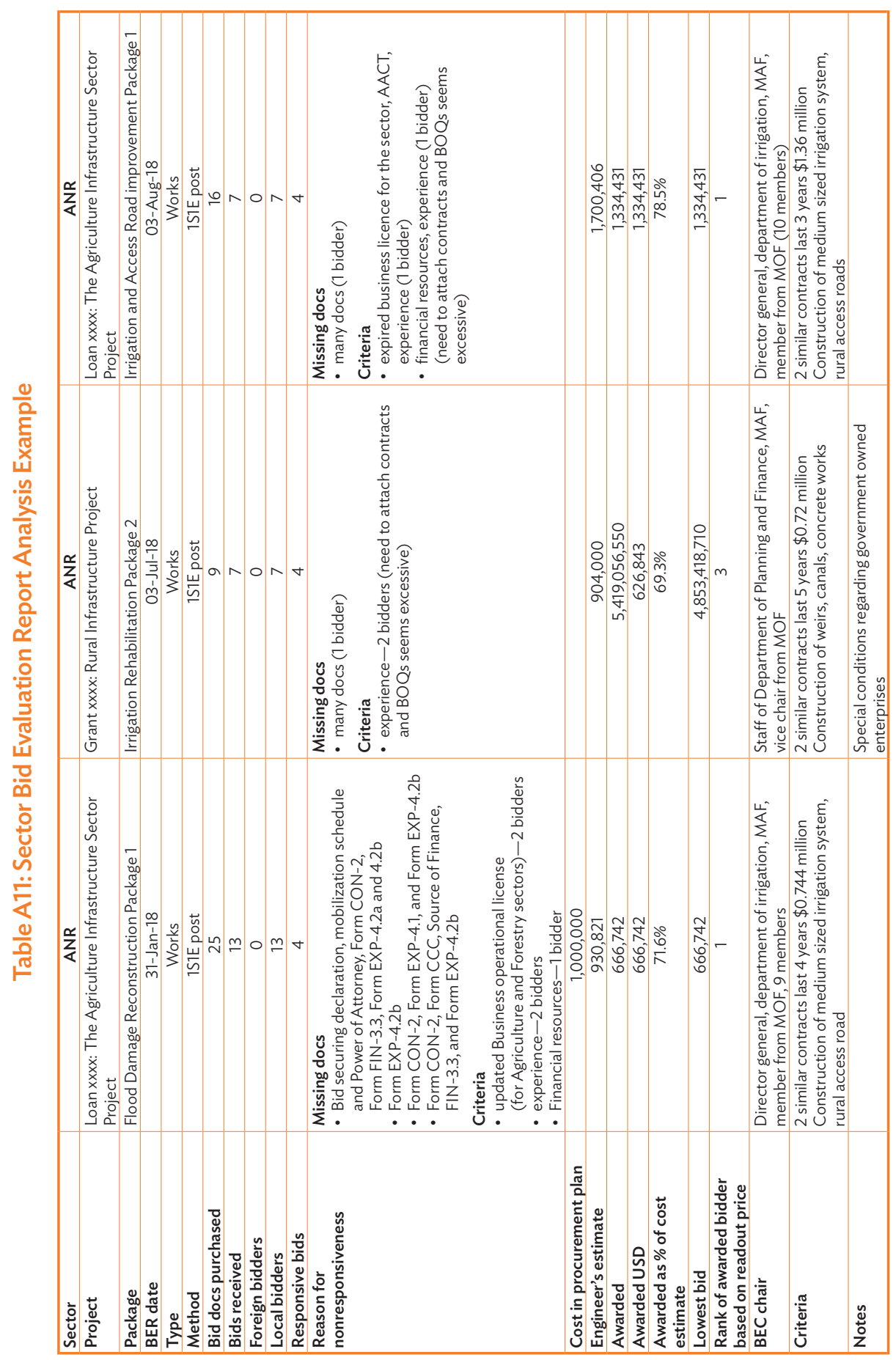




\section{Procurement Risk Framework \\ Guidance Note on Procurement}

The procurement risk framework emphasizes the need to treat and manage risks after identification and highlights risk management as an ongoing activity. This guidance note describes ADB's procurement risk framework for managing procurement risk throughout the procurement cycle. Effective risk management minimizes impacts on project objectives from adverse events. The guidance note describes how risks are identified, assessed, and managed at the country and sector/agency levels, and how those risks are used as inputs into the identification, assessment, and management of risk at the project level during procurement planning and through contract implementation.

\section{About the Asian Development Bank}

ADB is committed to achieving a prosperous, inclusive, resilient, and sustainable Asia and the Pacific, while sustaining its efforts to eradicate extreme poverty. Established in 1966, it is owned by 68 members -49 from the region. Its main instruments for helping its developing member countries are policy dialogue, loans, equity investments, guarantees, grants, and technical assistance.

\section{$\mathrm{ADB}$}

